\title{
EBÛBEKIR EFENDî XWOŞNAV (1814-1880): 'ALIMEKî KURD LI EFRÎQAYA BAŞÛR
}

\author{
M. Zahir Ertekin *
}

Bedrettin Basuğuy*

\section{Puxte}

Ebûbekir Efendî 'alimekî kurd ê sedsala XIXem e. Di dewra Sultanê Osmanî Ebdulezîz de (1830-1876) weke 'alimekî mezin û murşî̀ ji bo misilmanên Afrîqaya Başur di sala 1862an de hatîye şandin. Di sala 1880an de li wê derê wefat dike. Di vê gotarê de em li ser jîyan, têkoşîn û xebatên Ebûbekir Efendî disekinin û bersiva van pirsan didin. Ji Şeqlewayê çima bi malbatî hatine Erziromê? Li Erziromê çi kar dikir in? Piştre çima diçe Stenbolê û çawa hatîye bijartin ji bo şandina Efrîkaya Başûr? Herwiha ev xebat cara yekem e ku li ser Ebûbekir Efendî, bi kurdîya kurmancî hatîye amadekirin. Bi tirkî gelek xebat li ser wî hatine kirin. Romanek hatîye nivîsîn, sempozyûmek hatîye lidarxistin. Mixabin ji ber koçberkirina Ebûbekir Efendî ya ji Şeqlawayê ber bi Erziromê ve, piranîya çavkanîyên tirkan wî wek tirk destnişan kirine. Ev gotar, bersiva vê çewtîyêye jî.

Peyvên Sereke: Ebûbekir Efendi, Xoşnav, Efrîqaya Başûr, Beyânuddîn, Stenbol, Şeqlawa

\section{ABU BAKR EFENDI KHOSHNAWÎ (1814-1880): A KURDISH SCHOLAR IN SOUTH AFRICA}

\begin{abstract}
Abu Bakr Efendi is a nineteenth-century Kurdish scholar in South Africa. In the reign of the Ottoman Sultan Abdulaziz (1830-1876) he as a prominent scholar and religious guide was sent to South Africa in 1862 in order to educate the Muslims. Abu Bakr Efendi passed away in Cape Town in 1880. In this article, we deal with life and works of Abu Bakr Efendi and try to answer these these questions. Why did he migrate from Shaqlawa to Erzurum with his family? What was his mission in Erzurum? Then, why did he go to İstanbul and how was he sent to South Africa? This is the first time an article related to Abu Bakr Efendi prepared in Kurmanji Kurdish. Up to now, in Turkish many researches have been done on him. A novel was written and a symposiums was
\end{abstract}

Article Types/Makale Türü: Research Article/Araştırma Makalesi

Received/Makale Geliş Tarihi:15/01/201/, Accepted/Kabul Tarihi: 25/08/2019

Doi: $10.26791 /$ sarkiat.513170

*Doç. Dr. Bingöl Üniversitesi, Kürt Dili ve Edebiyat1. zahirertekin@hotmail.com

ORCID ID: https://orcid.org/0000-0003-3519-9892

*Dr. Öğr. Üyesi, Bingöl Üniversitesi, İlahiyat Fakültesi, İslam Tarihi Anabilim Dalı. bedricanan@hotmail.com

ORCID ID: https://orcid.org/0000-0001-7655-7559 
held on him. Unfortunately, because of his migration from Shaqlawa to Erzurum, many Turkish sources mistakenly identified him as Turkish. In this regard, this article discusses his identity, too.

Keywords: Abu Bakr Efendi, Khosnaw, South Africa, Bayan al-Dîn, Istanbul, Shaqlawa.

\section{DESTPÊK}

Ebûbekir Efendî ${ }^{1}$ 'alimekî kurd e ku dewleta Osmanî ew ji bo perwerdehîya îslamî, şandîye Efrîqaya Başûr. Eslê xwe ji Şehrezor/Şeqlawayê ye û cara ewil li medreseya ku ji alîyê Mîr Silêmanê bapîrê wî ve hatibû damezrandin dest bi tehsîla 'ilmê dike. Piştî wefata bavê xwe, ji bo perwerdehîya xwe bidomîne diçe Stenbolê û li wir perwerdehîya xwe kuta dike. Paşê diçe Bexdayê û dest bi mideristîyê dike. Dû re diçe Erziromê ku malbata wî koçî wê derê kiribû û li wê derê bi cih dibe. Ji Erziromê ji bo karên xwe yên taybet diçe Stenbolê û li wê derê tête wezîfedarkirin bo şandina Efrîqaya Başûr.

Armanca vê gotarê ev e ku, jînnameya alimekî kurd û kar û xebatên wî bide nasîn. Rêwitîya Ebûbekir Efendî ya Efrîqaya Başûr, kar û xebatên ku li wê derê kirine û heta wefata wî di çarçoveya çavkanîyên sereke de, di vê nivîsarê de cih digirin. Girîngîya mijarê ev e ku heta niha bi kurdî tu xebat li ser vî alimî nehatine kirin. Di nava 'eraban de wek 'ereb, di nava tirkan de wek tirk hatîye nişandan û nasandin. Ji ber ku ji teref dewleta Osmanî ve wek fermî hatîye erkedarkirin, pir derfet nebûye ku kurd, xwe bigihînin belge û arşivên di vê biwarê de. Loma bêtir weke 'alimeki tirk hatîye zanîn. Me jî xwest ku em vî zatî, li gorî rasteqînê vekolin. Lewra ew alimekî kurd e û yek ji bermahîyên medreseyenên Kurdistanê ye. Dema ku meriv bi vî awayî Ebûbekir Efendî binirxîne wê heqê wî were dayîn. Hêvî heye ku ev gotar bibe wesîle ji bo xebatên berfireh ên di vê biwarê de.

\section{Jîyana Wî}

Ebûbekir Efendî di sala 1814an de li Şeqlewayê hatîye dinyayê. (Gençoğlu, 2016: 26) Derbarê jidayîkbuna Ebûbekir Efendî de nelihevîyek heye, lê xebata ku Gençoğlu kirîye, derbarê vê mijarê de axir xebat e, ev gengeşî ji holê rakirîye. Lewra Gençoğlu dibêje ku di pasaporta wî de ku bi frensî ji alîyê dewleta Osmanî ve hatîye amadekirin de, sal 1862 û 48 salî derbas dibe. Eger di sala 1862da de 48 salî be, teqez divê di sala 1814an de hatibe dunyayê. (Gençoğlu, 2016: 27) Herwiha xebata derbarê Ebûbekir Efendî de ya herî berfireh a Ahmet Uçar e. Uçar jî bêyî ku jêderê nîşan bide dibêje Ebûbekir Efendî di sala 1823an de hatîye dinyayê ku ev jî şaş e. (Uçar, 2008: 129) Ji ber ku Gençoğlu bi belgenameyekê temenê wî û tarîxa ji dayikbûna wî teqez dike, em jî ji dayikbûna wî wek 1814 dipejirînin.

Di çavkanîyan de cihê jidayikbûna wî wekî Xwoşnav derbas dibe. Wî bi xwe jî nasnava Xwoşnavî bi kar anîye. Zimannasê zimanên Semîtîk Adrianus Van Selms di salên 1950an de li gel Celâleddîn Ömerê kurê Ebûbekir Efendi hevpeyvînekî çêdike û ev hevpevîn di kitêba The religious duties of Islam as taught and explained by Abu Bakr Effendi de tê çapkirin. Di vê hevpeyvînê de Celâleddîn Ömer dibêje ku bavê wî zêdetir

\footnotetext{
1 Peyva Efendî ji "afêndis"a Bîzansî derbasê Tirkî bûye û di wateya "sâhîb" yan "mâlik" de hatîye bikaranin. Di lîteratûra Osmanî de nasnava "Efendi" ji bo dîyarkirina esaletê û ji bo karmendên payebilind wekî nasnaveke fermî hatîye bikaranîn. Bnr. (Köprülü, 1994, 10: 455; Genceoğlu, 2014; 94)
} 
bi nîsbeya Xwoşnavî hatîye naskirin. (Brandel, Syrier, 1971: 6-15) Martîn Van Brunessen ji dibêje nevîyên Ebûbekir Effendi Îsmet Efendi ji min re kopîyeke şecera malbata xwe şand û di vê şecerê de Ebûbekir efendî nîsbeya Xwoşnavî ji bo xwe dîyar kirîye û gotîye ku "ez ji eşîreta Xwoşnavê me û ev eşîret li rojhilata Erbîlê de jîyana xwe didomîne". (Bruinessen, 2000: 133-141) Navê Ebûbekir Efendî di arşîva Osmanîyan de, di hin belgenameyan de wekî Bexdadî di hin belgenameyan de jî wekî Şehrezorî hatîye nivîsîn. (Marufoğlu, 1988: 65) Bavê wî Mela Omer e. Navê dîya wî nayê zanîn lêbelê li gorî angaşta hin eqrebayên wî yên ku niha li Cape Townê/kepîya hêvîyê dijîn, navê dîya wî Fehîme ye, lê ev angaşt, xwe naspêre belgenameyan. Navê keça Ebûbekir Efendî jî Fehîme ye, dibe ku navê dîya xwe li keça xwe kiribe. Ebûbekir Efendî xwendina xwe ya seretayî li medreseyê xwendîye ku ji alîye bapîrê wî yê bi navê Emîr Suleyman ve hatibû damezrandin. Piștî wefata bavê xwe, ku muderisê medreseyê bûye, ji bo xwendina xwe ya medreseyê tê Stenbolê. 5 salan li wir dixwîne. Derbarê vê serdema Ebûbekir Efendî de tu agahîyên berdest û teqez nînin. Yanê em nizanin li ku dixwîne, li cem kê îcaza 'ilmî-zanistî werdigire û bi çi rengî tête şandin bo Bexdayê. Piştî ku îcazeta xwe li Stenbolê werdigire, bo muderistîyê te'yînî Bexdayê dibe. Di sala 1852yan de vedigere Şeqlawayê û dibe mutewellî û muderrisê medreseya Emîr Suleyman. Dema ku li vê derê wekî fermî karê xwe yê muderistîyê bi rê ve dibir, ji ber îstîlayeke bedewîyan ya bi ser Şeqlawayê, naçar bi malbatî koçî Erziromê dike. Di hin çavkanîyan de ev, îstîla nîne, serîrakirina Xoşnavîyan a li hember bacê ya 'eşîrên kurdan e. Li ser vê 'isyankarîyê bavê Ebûbekîr Efendî, Mela Omer di medreseya xwe de tête kuştin. Li ser vê yekê malbat, malê bar dikin û diçin Erziromê. (Gençoğlu, 2016: 27) Sedema hilbijartina bajarê Erziromê jî aşkera nîne. Gelo çima bajarekî din na, lê Erzirom? Lê hin çavkanî dibêjin ku hin eqrebayên Ebûbekir Efendî ji berê de çûne Erziromê. Ji ber ku nasên wan hebûne li Erziromê, wan jî bi malbatî koçî wê derê kirine. Lê di vê koçê de ji malbata wî kî hebûne, baş dîyar nîne. Li Erziromê di sala 1861an de dibe muderisê medreseya Sarayönüya li Erziromê û malbata Ebûbekir Efendî li vê derê li mala muderis Seyid Ehmed Efendî bi cih dibin.(Gençoğlu, 2016: 34; Uçar, 2008: 134)

\section{Malbata Wî}

Di çavkanîyan de Ebûbekir Efendî kurê Mela Omer kurê Mewlana Selaheddîn kurê Mela Mustefa Beg kurê Emîr Suleyman e (Kavakç1, 1976: 168-173) û navê dîya wî derbas nabe. Di belgeyeke ku Halim Gençoğlu weşandîye de, şecereya wî wiha derbas dibe. "Ebubekir kurê Mela 'Umer Kurê Selahedîn Mela Mistefa Kurê ......................urê Mela Mistefa Kurê Mela Îbrahîm Kurê Mîr Silêman Kurê Mîr Mihemed Kurî 'Ezudedîn Kurê 'Ebdilla Kurê 'Îzzedîn Mihemed Kurê ................. Kurê................. Kurê Mîr Silêman Xazî Qureyşî el-emcedî." (Bnr. Wêne-11) Sê caran zewicîye. Cara yekê li Erziromê bi eqrebayeke xwe re dizewice. Em derbarê vê zewacê de agahîyên misoger nizanin.

A duyem bi Ruqîye Maker re dizewice. Ev zewac piştî ku diçe Cape Townê bi sê mehan, 8 Nîsan 1863an de pêk tê. Ji vê zewacê du zarokên wî çêdibin. Yek di biçûkatîya xwe de wefat dike. Yê din jî navdartirîn û zanatirîn kurê wî Ehmed 'Etaullah Efendî $\mathrm{ye}^{2}$, ku paşê dibe yekem sefîrê Osmanî yê Sîngapûrê. (Gençoğlu, 2016: 35) Di

\footnotetext{
${ }^{2}$ Ehmed Etaullah (1865-1903), dibe yekem rêvebirê mekteba Osmanî ya ku di sala 1884an de li Kimberleyê vebûye. Paşê dibe yekem konsolê Sîngapûr ê Osmaniyan. Xebatên kurê wî Ehmed Etaullah gelek mezin in û li ser wî û xebatên wî yê konsoliya Sîngapûrê bûye mijara pirtûkekê ku ji layê konsola
} 
demeke kin de zewaca Ebûbekir Efendî û Ruqîye Xanimê diqede û hevdu berdidin. Di sala 1866an de Ebûbekir Efendî bi Tahora Saban re dizewice ku bi 'eslê xwe îngilîz e. Ji Tahora Xanimê pênc zarokên wî têne dinyayê. Li gorî kronolojîya temenê wan; Fehîme, Hîşam Nimetullah, Muhemmed 'Elaeddîn, Omer Celaleddîn û Huseyîn Fewzî ye. Fehîme keça wî ya yekane ye. Bi alimekî mezin Seyid 'Ebdulrezaq 'Ilmî Efendî̀ re dizewice û vedigere Tirkîyeyê. Nevîyên wan hê jî li Stenbolê û li Erziromê hene. (Gençoğlu, 2016: 42) Hîşam Nimetullah di sala 1867an de li Cape Townê hatîye dinyayê. Li el-Ezhera Misrê xwendina xwe kuta dike. 'Ewil 1890an li Mekkeyê paşê di 1894an de li Stenbolê payeya muderistîyê werdigire. Ji alîyê Ebdulhemidê duyem ve bi Nîşaneya Mecîdîyê tête taltîfkirin. Berhemên wî yên derbarê şerîetê de bi herfên 'erebî bi zimanê filemenkî hatine weşandin û bûne pirtûkên dersan ên mektebên Cape Townê. (Gençoğlu, 2016: 34-44) Muhemmed 'Elaeddîn qarîekî Qurana pîroz ê navdar bûye û dirûnkerî kirîye. Omer Celaleddîn di 1872an de li Cape Townê hatîye dinyayê.

Uçar, derbarê weqfeke malbata Ebûbekir Efendî de agahîyên taybet dide. Uçar dibêje ku di arşîva Hîşam Efendî ya taybet de weqfîyeyek heye, ku ev weqfîye derbarê malbata Ebûbekir Efendî de hin agahîyan dide. Ev weqfîye li ser navê bav-kalê Ebûbekir Efendî, Ebû Nasr Emîr Suleyman el Gazî hatîye dirustkirin. Di vê weqfîyeyê de piştî besmele, hemdele û selweleyê, behsa fezîlet û xêrên damezrindina weqfê hatîye kirin. Emîr Suleyman di weqfîyeyê de dibeje ku min, ji bo xwendina 'ilm û zanistê li Sîyawanê weqfek ava kirîye. Dahat/aqar û warîdatên emlaqa ku bi navê Xana Ehmer meşhûr bûye, dahatên goristana Xerda û Sîyehzemînê, dahatên 5 erdên ku li Surrîyêne bo vê weqfê hatîye terxankirin. Dahatên weqfê ji xwendekar û hîndekarên 'ilmê nebewîyê re ne. Yên mayî jî, ji xwendekarên medreseya Emîr Suleyman re ye. (Uçar, 2008: 131) Ji bo şertên mutewelîbûyîna vê weqfê jî wiha hatîye gotin: Divê Nazirê (mutewellî) vê medreseyê heman demê de muderisê vê medreseyê be û kar û barên li jorê hate gotin bi rê ve bibe. Divê piştî 'Emîr Suleyman kurê wî Ebu'l Muhsîn Mela Osman Hamid bibe Nazirê weqfê û kar bike. Piştî wî jî ji kurên wî yê herî 'âlim û salih, divê vî karî berdewam bike. Piştî kurên wî jî, ji nevîyên wî yê herî teqwa, divê vî karî bidomîne. Eger di nesl û nesebê de înqirazek çêbû, divê ji eqrebayên alîyê jinê, kesekî bi teqwa û salih vî karî bimeşîne. Eger hîç kesek ji eqrebeyan jî nemîne, qazîyê Xoşnavê divê kesekî maqûl peyda bike û bike serperiştê vî karî. Herwiha hatîye beyankirin ku kî rabe û şertên weqfê biguherîne ji bo wan jî cezayên giran hatine destnîşankirin, di weqfîyeyê de. Ev kevneşopîya rêvebertîya weqfê heta Ebûbekir Efendî hatîye meşandin ku Ebûbekir Efendî di sala 1852 de li ser karê rêvebertîya vê weqfê bûye. Uçar, di berhema xwe de destnîşan dike ku derbarê vê belgeyê de Hîşam Nimetullah Efendî alîkarî daye wî û herwiha belge jê re şandîye, ku Hîşam Nimetullah yek ji nevîyên Ebûbekir Efendî ye û li Cape Townê dijî. Herwiha dibêje heman belge bi nusxeyeke cuda ji lawê Kerîme Xanimê ku ew jî nevîyê Ebûbekir Efendî ye, hatîye şandin. (Uçar, 2008: 131)

\section{Wêneyên Wî}

Li gorî xebata ku me kirîye tenê wêneyekî Ebûbekir Efendî hatîye peydakirin. Di vê wêneyê de jî cilûbergên reş li Ebûbekir Efendî pêçayî ye, şaşika wî mezin û spî ye û rîyê wî reş xuya dike. Wêne di sala 1863 an de hatîye kişandin. Ev jî miqabilî sala wî ya 'ewil a çûyîna Efrîqaya Başûr dike. Di binê vî wêneyî de bi tîpên 'erebî wiha hatîye

Sîngapûrê çap bûye. Lê vê derê şayanê gotinê ye ku, divê xebatên serbixwe li ser vî kurê wî jî bêne kirin. Bnr. (Seben, 2014).

${ }^{3}$ Seyid 'Ebdulrezaq 'Ilmî Efendî hem apê Omer Nasuhî Bilmen e hem jî seydayî wî ye, ku Bilmen xwedîye mezintirîn tefsîra Tirkî ya navdar e. (Yaran, 1992, 6:162). 
nivîsîn: "Ebûbekir Efendî el Behr'-ul Muheqqîq Wel'-Hibr'ul Mudeqqîq Şeyx'ul 'İlm Şeyx'ul Îslam 'Ebdullah Ebûbekir Efendî el -Xoşnawî el Qureyşî̀ el-Emcedî we Muftî̀ Erbee' El'ê̂mma Me'mûr El dewle El Osmanîyye Îla Cenûbî Efrîqa Lin-neşrî El'Ûlumu'ddînîyye Wel Me'arîfî̀ El Rebbanîyye Fî Sene 1278 Mewlana Ebûbekir Efendî Îbn Mela 'Omer Beg... Îbn Eb̂̂ Nasr El-Emîr Suleyman el Xazî el Qureyşî el Emcedî̀"(Gençoğlu, 2016: 194) ev sifetên ku ji bo wî hatine pesinandin, ji alîyê kê û kengî hatine dayin ne dîyar e. Lê tenê di vê navandin û nasandinê de tê dîtin ku Ebûbekir Efendî wekî Şeyx'ul Îslam hatîye nasandin.

\section{4. Çûyîna Wî Ya Efrîqaya Başûr}

Efrîqaya Başûr di sedsala çardehem, bi taybet bo dewletên Ewropî bûbû cîyê balkêşî û girîngîyê. Bajarê wî yê dîrokî Cape Town, di sala 1488an de ji hêla deryavanên Portekîzî ve hatîye keşifkirin. Bajêr di nav demê de, bi çanda holandîyan û îngilîzan ve têkildar bû. Misilmanên 'ewil di serê sala 1700an de hatin vî bajarî. Misilmanên ku di demeke kin de mizgefta yekem a bajêr çêkirin, dema rastî zexta ewropayîyan hatin, ji bo xwe biparêzin mecbûr man ku têbikoşin. Bi taybetî Holanda heta sedsala hîjdehem bi Bengalîyan re li Efrîqaya Başûr ketin herbên kolonyalîst. Di encama van şeran de di destpêka sedsala nozdehem de îngilîzan serdestîya holandayîyan a li Efrîqaya Başûr ji holê rakirin û bûn tekane kolonyala Efrîqaya Başûr. Destpêka îslamî ya Efrîqaya Başûr xwe digihîne demên dirêj ên berîn ku hin misilman ji berê de li wê derê bûn. ${ }^{4}$

Lê di asta têkoşineke berfireh û di wateya teblîxeke têkûz de dînê îslamê, di sedsala hejdehem de bi saya Şêx Yûsif û TuanGuru kete halekî sîstematîk. Di vê serdemê de ji bo misilman û kêmarên din, hin serbestî hate dayîn. Gelê 'ewil ê Efrîqaya Başûr ji niştecihên bendepêk dihat $\mathrm{ku}$ ji Endonezya, Malezya û Hindistanê hatine anîn û misilmanên hatine mehkûmkirin, an jî ji ber sedemên sîyasî hatine nefîkirin. Piştî nifûsa misilmanên kole li vir zêde dibe ew di nav xwe de rêbazan ava dikin û bi van rêbazan hewl didin, dînê xwe biparêzin. Di salên 1850î de serjimara misilmanan zêde dibe, lêbelê misilman bi rastî û dirustî dînê xwe û ehkam û pêdivîyên wê baş nizanin. Loma jî ji bid'eyan/xurafeyan hin nakokî û têkoşîn di navbera misilmanan de derdikeve.Kesên hafiz bûn, Qur'ana Pîroz dinivîsandin, yên dua û ayet dizanibûn jî hertim ew dubare dikirin da ku ew di hişê wan de bimîne. Paşê di sedsala 19emîn de misilmanên eslê xwe ji Hindistan û Malezyayê ne derbarê tetbîqkirina rê û rêbazên îslamê de ji ber ku cuda tevdigerîyan di navbera wan de îxtilaf çêbû. (Sirma, 2018: 2)

Misilmanên Efrîqaya Başûr, bi taybet dema ku di binê mêtingeha Holandaya de bû, gelek zilm û tedeyî dîtine. Vê dewrê û piştre jî misilmanên vê derê ji zanînên sererast bêpar bûn. Ji xwe ji ber vê yekê nakokî ketibû nava misilmanan. Bi taybetî dema ku misilmanên vê derê diçûne hecê, didîtin ku hemû zanîn û kirinên wan ên derbarê îslamê de şaş in, vêca vedigerîyan memleketê xwe û behsa şaşîyên xwe dikirin, lê kes bi vê yekê qani' nedibû. Ev gengeşî carna dibû sedema nîqaşên tund. Kom di nava xwe de ava dikirin û dibûne duserî. Bi navê Tarîef grûbek hebû û hinan jî xwe wekî pêgirên xelîfe Ebdulmecîd dipejiradin. Car caran jî şer di navbera wan de derdiket. (Lütfi, 2013: 22-23)

\footnotetext{
${ }^{4}$ Di salên 1800î de ji Hindistan û Malezyayê misilmanan koçî Cape Townê kirine. Kepiya Hêviyê ji 1805an vir ve di bin hakimiyeta îngilîzan de ye. Îngiliz zordestiyê dînê nakin, lê derfetê nadin misilmanan ku ew di navbera xwe de li hev bikin jî. Pevçûnên di navbera misilmanan de tu carî xilas nabe. Cudahiya tetbîqkirina rê û rêbazên îslamê hema bêje di navbera misilmanan de qasî ku bibe sedema şerê navxweyî zêde ye. (Kurtuluş, 1996, 14:301).
} 
Di salên 1800î de misilmanên ku li Cape Townê jiayane, di nav xwe de komîsyonekê ava dikin û diçin cem walîyê îngilîz ku ew bi wesîleya Qraltîya Îngîlistanê ji Dewleta Osmanîyan a ku serokê misilmanên dinyayê û xelîfeyê misilmanan e, alimekî dînî bixwazin ku ew Îslamê li gor eslê wê vebêje û lihevnekirinên di navbera wan de çareser bike. Sereta îngilîzan ev yek qebûl nekirin. Paşê ji ber bêaramîya Cape Townê ya ji ber gengeşîya misilmanan razî bûbûn. 'Ewil bi nameyekê serî li walî didin. Paşê walî daxwaznameya wan ji Keybanû Vîktoryayê re, Keybanû jî bi wasîteya konsolosê Osmanî yê Londonê Musurus Paşayî re dişîne paytexta Osmanî. (Lütfi, 2013: 22-23) Bi daxwaza Siltan 'Evdilezîz; rewşa misilmanên Efrîqaya Başûr û daxwaza wan li nava Heyeta Wukelayê de tê nirxandin. Di encama vê civînê de hate eşkerekirin ku misilmanên Efrîqaya Başûr, bi vê nameyê pesend kirine ku pihêt bi dewleta Osmanî ve girêdayî ne. Xîlafeta Kubra ya Osmanî ji xwe re wekî serok û serkirde dipejirînin. Divê teqez pirtûkên mesaîlên dînî ji wan re bête şandin, lê ev têrê nake. Bi pirtûkan re divê 'alimekî ku feraseta wî zahir/aşîkar e jî̀, ji wan re bê şandin, da ku bikaribin dubendî û cîyawazîyên navbeyna xwe sererast bikin û bibin xwedî hakemekî rast û dirust ê îslamî. (Uçar, 2008: 164)

Heyeta Wukela vê encamnameyê pêşkêşî Siltan 'Evdilezîz dike. Siltan jî bo pêkanîna vî karî biryarê dide û Meclisa Wukela ya Ehkamê 'Edlîyeyê bi vî karî re erkdar dike, dixwaze demildest çareserîyekê encam bidin. (Uçar, 2008: 164) Li ser vê emirnameyê Babî 'Alî li 'alimekî ku bişînin Efrîqaya Başûr digere. Wezîrê karê derve yê wê serdemê 'Elî Paşa dixwaze ku Ehmed Cewdet Paşa vê kêşeyê çareser bike, kesayetekî peywirdar û şayeste bibîne, peyda bike û bibijêre. Li gorî vekolîna Ahmed Cevdet Paşa, Ebûbekir Efendî $^{5}$ dibe yekem kesê şayeste yê bo şandina Efrîqaya Başûr. Lewre li gorî şertên kesê ku bête bijartin, ên Meclîsa Wala danîbû ev bûn;

- Divîya 'erebî baş bizanibe,

- Bikaribe bikeve ser kurm û kirasên niştecihan.

Li gorî van şert û mercan, Ebûbekir Efendî dikeve ezmûna mulaqatê û serkeftî dibe. Li gorî encama vê ezmûnê wesfên Ebûbekir Efendî wiha hatîye danîn: "Metanet-î ilmîyye, dirayet ve fetanet-i fitrîyesini matlûba muvafik bularak..." ango di 'ilm û zanînê de xwedan metanet e, fetaneteke wî̀ ya fitrî jî heye ku ji bo bijartinê muwafiq e. (Baktır, Eeraslan, 1994: 276)

Li gorî biryara ku lijneyê daye, Ebûbekir Efendî, ji bo xercerêya heta Londonê 7.500 quruş pere dê bê dayîn. Ji bo mezaxtin û xerckirinên Londonê û heta çûyîna Cape Townê jî hemû mesarîf dê ji layê sefareta Osmanî ya Londonê bê dayîn. Ji bilî van, bo Ebûbekir Efendî, bo memurîyeta wî ya Cape Townê, her mehê 25 lîra dê bê terxankirin û mehaneya wî dê, bê navber, bi pergal bê şandin. Meclîsa Wala vê biryarê di 17ê gulana 1862an de distîne û Siltan 'Evdilezîz jî di 26ê gulana heman salê de tewqî' dike. Li ser vê yekê Ebûbekir Efendî û birazîyê xwe Lutfî Efendî bihevre dikevin rê. Ebûbekir Efendî di 8ê Rebîulewwela sala 1862an de, ji Stenbolê bi rê dikeve û ji ser

\footnotetext{
5 Ebûbekir Efendî tevî malbata xwe li Erziromê jiyana xwe didomandin. Di vê meseleya daxwaza misilmanên Efrîqaya Başûr de, Ebûbekir Efendî jî hesbelqeder li Stenbolê bû. Sebebê hatina wî jî ev bû. Ebûbekir Efendî dema ku Adara 186an li Erziromê li Medreseya Sarayönüyê dest bi wezîfeya muderistiyê kir, di nava mehan de meaşê xwe sererast nedistand, ango mehaneya wî nedihat razandin. Him ji ber vê yekê him jî ji bo xwe bigihînê agahî û belgeyên derbarê Weqf û Zawiyeya Mela Hesenê Banûkî el Mûşî ya li Gundê Tîlê, hate Stenbolê da ku here erşîvxanya Osmanî. Hatina wî ya bi van mebestan û bijartina wî ya ji bo Efrîqaya Başûr rastî hev hatibûn. Êdî Ebûbekir Efendî careke din venegeriya Erziromê. (Uçar, 2008: 135).
} 
Parîsê derbasî Londonê dibe û li wê dere, bi rayedarên karên derve yên îngilîzan re hevdîtin pêk anî. Piştî ku 2 mehan li Londonê dimîne, li Lîverpoolê li keştîyê siwar dibe û di 26ê Receba sala 1279an (17ê çileya sala 1863an) de digihêje Cape Townê.

Ebubekir Efendî û Lutfî Efendî 'ewil bi rêya behrê diçin Marsîlyaya bajarê Fransayê, ji wir bi trênê diçin Parîsê û paşê jî diçin Londonê. Demekê li Îngilistanê dimînin û paşê bi rêya behrê diçin Cape Townê. Misilmanên Efrîqaya Başûr bi coşeke xuroşî Ebûbekir Efendî pêşwazî dikin. Ji wê rojê heta wefata wî (1880), xebateke cidî ya îslamî û teblîxa wî destpê dike.(Lütfi, 2013: 25)

16 Çileya 1863an de digihîjin Cape Townê. Çawa ku xwe digîhînin Cape Townê Konsolosê Fexrî yê Osmanî yê Efrîqayê Petrus Emanuel De Roubaix wî pêşwazî dike. Roubaix çendîn ku dixwaze li erebeya hespînê suwar bibe jî, ew ji bo hurmetnîşandana gel bi meşê çûye heta nava bajêr. (Lütfi, 2013: 43)

Kurê wî Celâleddîn Omer di derbarê serpêhatîya çûyîna bavê xwe Ebûbekir Efendî ya Efrîqaya Başûr waha dibêje:

"Dema bavê min digîhîje koşka siltan a Stenbolê serokwezîrê wê demê Xelîl Paşa û yaverê siltan, Osman Paşa li ser pêhlikên pêşgeha koşkê de sohbet dikirin. Dema ku bavê min dibînin bikêfxweşî ji hev re dibêjin "Va Ebûbekir Efendî hat. Ew alîkarîyê ji bo xelqê xwe ji me dixwaze lê em di vê meselê de nikarin tiştekî bikin. Lê bele me ji qraliçe Vîktorîyayê nameyek wergirtîye. Tebaa wan yên Misilman yên kolonîya Capeyê di derbarê problemên dînî de alîkarîya jê dixwazin, ta ku ji siltan rica bike ku alimekî pisporê dîn ji wan re bişîne. Haydê em Ebûbekir Efendî bişînin. Bi vî awayî bavê min dişînin Îngilistanê. Di Londrayê diçe koşka qralîçê, lê Lord Chamberlain jê re dibêje ku qraliçe ji bo zîyaretekê çûye Skotlandê. Lord Chamberlain bi mîsyona bavê min re gelekî eleqedar dibe û jê re dibêje ku keştîyek sibetirî dikeve rê ji bo Capeyê û ji bo çûyîna te çi ji deste min were ezê bikim.

Bavê min wexta ku digîhîje Cape Townê dibîne ku tu kes li benda wî nîne. Sê roja di Hotela Royalê de dimîne û bi awayekî endîşedar li benda zîyaretvana dimîne lê belê kes nayê. Di dawîyê de katibekî Hollandî Cemaeta Malayî ji hatina mêvanekî bijarte agahdar dike û resepsîyoneke mezin bi lez tê tertîpkirin. Paşê Ebûbekir di koşeyê cehdeyên Bree û Waleyê de malekî distîne û li wir dest bi dayîna dersan dike. Pişt re jî di kuncika cehdeyên Lang û Dorpê de mizgeftekî ava dike." (Brandel, Syrier, 1971: 1718) divê were gotin ku di pêşwazîkirina Ebûbekir Efendî de du rîwayetên ji hev cuda hene. Li gorî kurê wî, tu kesî ew pêşwazî nekiribû û li gorî Lutfî Efendî, bi awayekî coşane hatibûn pêşwazî kirin. Bi raya me divê bi coş hatibin pêşwazî kirin, lewra Lutfî Efendî digel Ebûbekir Efendî bû û şahidê vê bûyerê bibû.

\section{Xebat Û Têkoşînên Wî}

Wexta ku Ebûbekir Efendî diçe Cape Townê, bala xwe dide rewşa misilmanên wê derê, di destpêkê de bêhêvî dibe. Lewre rewş gelek aloz xuya dike. Vê rewşê, hetta nîyeta xwe ya vegerê bi nameyekê ji Stenbolê re dişînê. Bersivên ku ji wî re tên, hêvîyên wî geş dikin û ji fikra xwe ya bêhêvîyêtîyê zû bi zû rizgar dibe û dest bi kar û xebatên xwe dike. Ebûbekir Efendî sereta mektebekê vedike. Navê wê Ottoman Teological School e, ango Mekteba Îlahîyatê ya Osmanîyan.(Uçar, 2008: 146; Geçoğlu, 2016: 30) Hemû mesrefên mektebê ji hêla Dewleta Osmanî ve tê dayîn. Lê ev ji bo wî ne bes e. Bi fedakarîyeke mezin li ser navê xelîfe mizgeftekê dide çêkirin. Di nav heft mehan, yanê demeke kin de zimanên herêmî û pê re jî îngilîzî hîn dibe. 17 salên ku li Efrîqaya Başûr maye dibe wesîle ku bi sedan xwendekaran bigihîne. Wisa ku xwendekarên wî piştî 
salan li Londonê jî mizgeft dane çêkirin. Cape Towna ku îro nifûsa wê 3,5 milyon e, sê paran yek ji misilmanan pêk tê ku ev hinekî bi saya wî û Osmanîyan e.

Ebûbekir Efendî li Cape Townê ji alîyê walîyê giştî û xelkê herêmê ve bi "eleqeyeke mezin tête pêşwazîkirin û ji rojnameyên mehelî re dibe mijar. Li vê derê jê re malek û tercimanekî ku bi erebî û felemenkîya mehelî baş dizanibû tête dabînkirin. Ebûbekir Efendî di encama lêkolîn û vekolînên ku li herêmê dike, van tiştên ecêb ên ku bune bawerîya millet tesbît dike: Kesên rihê xwe jê bike ew ê bibe kafir û dê nimêja wî ya cinazê neyê kirin, kesên ku simbêlên xwe jê nekin dê misilman neyên hesibandin, tiştekî ku cureyeke enfîyeyê ye û tê cûtin rojîyê xera nake, ger mehr ji 5 şîlînê (wê demê ev yek teqabûlî 27,5 qirûşan dikir) zêdetir be dê nikah ne sahîh be, di dema mehrbirînê de divê her du teref hevdu hemêz bikin û maç bikin. Herwisa Ebûbekir Efendî li herêmê dît ku xelk di warê şêwaza definkirina cinazeyê de jî nîqaşên bêwate dikin û dibêjin gelo dema ku cenaze hat definkirin divê ewil serî bê binaxkirin yan pîyên wî? Ji bilî van yekan Ebubekîr Efendî dibîne ku hinek kes li wê derê bi nav û wesfên meletî û ehlê tesewwûfê xelkê di warê dîn de dixapînin. Ji bo vê cehaletê ji holê rake, Ebubekîr Efendî pêşî giranîya xwe dide ser perwerdehîyê û li navenda Cape Townê bo zarokên kurîn mektebekê vedike. Digel alîkarê xwe yê bi navê Omer Lutfî, pêşî xwendina Qur'ana Kerîm hînî zarokan kir û ew kesên ku hafiztîya xwe qedandin wekî xoce îstîhdam kir. Piranî di warê eqaîdê de Fikhu'l-ekbera Ebû Hanîfe û di warê fiqihê de jî Multeka'l-ebhura Halebî di perwerdehîya zarokan de bikartîne. Herwisa bo mezinan jî êvaran bernameyeke cuda birêkdixe. Roja yekşeman ji tefsîra Rûhu'l Beyan we'zan dide û bo jinan jî mektebekê vedike. (Baktır, Eraslan, 1976: 276)

Ebûbekir Efendî ji alîyekî ve dest bi perwerdekirina zarokan dike û ji alîyê din ve jî bo kartêkirina xwe zûtir li ser xelkê dayne digel filemenkîya mehelî û îngilîzî jî hîn dibe. Bi destûra walîyê giştî di nav xelkê de dest bi fealîyetên teblîxa Îslamê kir. Misilmanên ku li bajarên derdorê dijîyan û bi weşanên ku derheqê wî de derdiketin jê haydar dibûn, bo meseleyên dînî jê pirs bikin, carna ew bixwe dihatin balê û pê re hevdîtin dikirin û carna jî ew vedixwendin û jê dixwestin ku were nav wan û demekê di nav wan de bimîne û fealîyetên îrşadê bike. Ebûbekir Efendî di çarçoveya van çalakîyan de çend caran çû Mozambîkê. Encax xebatên wî hertim birêkûpêk nedimeşîyan û carna rastî zehmetîyan dihat. Lewre hin mela li ser misilmanên ku rewşa wan a aborî ne xirab bû û piranîya wan ji esnafan pêk dihatin û mensûbên mezheba Şafîi bûn bibandor bûn. Ev jî kêşeyek bû û divîya bête çareserkirin. Tuan Guruyê ku di sala 1807an de wefat kiribû yek ji wan hîndekarên herî mihim ê mezheba Şafîi yê li herêmê bû û nevîyên wî bi xwe jî bûbûn telebeyên Ebûbekir Efendî. Lêbelê Ebûbekir Efendî digel vê yekê dîsa rastî mixalefeta melayên herêmê dihat û ew melayên ku jê re mixalefet dikirin, ji xelkê re digotin kesên ku mezhebên din hilbijêrin dê bibin kâfir û misilmanên ku seadeta axretê dixwazin mecbûr in ku bi mal û kedên xwe ji wan re bibin alîkar. Encax walîyê giştî yê îngilîzan ê herêmê bi alîkarîya wan misilmanên ku berî niha çûbûn hecê û bawerîya rastî li wê derê hîn bûbûn bi ser ket ku van probleman çareser bike. (Baktir, Eraslan, 1976: 276)

Çendî ku cemaata Malayê bi piranî Şafiî bûn û Ebûbekir Efendî bi xwe jî alimekî Şafiî bû jî, wî dersên xwe yên fiqhê li gor mezhebê Henefî dida ku ev mezheb, mezhebê fermî yê dewleta Osmanî bû. Ebûbekir Efendî dema ku medereseya xwe vedike misilmanên Capeyê vê medresê wekî medreseyek Şafiî dizanin (Bruinessen, 2000: 136). Dîroknas Achmat Davids ê ku li ser misilmanên Capeyê çend xebatên wî hene, îdîa dike ku Ebûbekîr Efendî medreseya xwe li ser navê mezhebê Şafiî vekirîye. (Davids, Costa, 1994: 86) Lê waxta ku mudaxilê prisgrikên olî yên cemaata Malayê dibe wekî 
alimekî Henefî̀ tê naskirin. Di rastîyê de, di vî babetê de şuhreta Ebûbekir Efendî, piştî nivîsandina kitêba Beyânü'd-Dînê belav dibe. Ji ber ku ev kitêb li gor mezhebê Henefî hatîye nivîsandin û bingeha metna Erebî ya vê kitêbê dispêre kitêba Mülteqa'l-Ebhûr ${ }^{6}$ ku anegorî fiqha Henefî hatîye nivîsandin (Bruinessen, 2000: 136).

Her çiqas kû Ebûbekir Efendî di muqeddîma Beyânü'd-Dînê de, xwe wek miftîyê çar mezheba dide naskirin û di sala 1873 de di dadgehekê de xwe wek alimekî Şafiî dide naskirin jî̀, muxalifên wî qanî nabin ku ew Şafî̂ ye. Hetta ji alîyê muxalifên xwe bi îddîaya seba ku padiş̧ah meaşê wî zêde bike heta ku ji destê wî tê Şafiîyan dixe Henefî, tê tawanbarkirin. (Bruinessen, 2000: 136) Ji alîyekî din ve ji van îthaman eşkere dibe ku di nav Cemaata Malayê de dubendîyen mezhebî zêde bûne û ev îxtîlaf jî xebatên Ebûbekîr Efendîyên di warê teblîx û îrşadê dijwartir kirine.

Ebûbekir Efendî û telebeyê wî Omer Lutfî̀ 'ewil her çiqas rastî pirsgirêkan bên jî̀, paşê serkeftî dibin ku misilmanên bûne dijminên hevdu li hev bînin. Piştî sê salan yanê di sala 1866an de Omer Lutfî Efendî vedigere welêt û Ebûbekir Efendî bi tenê li Kepîya Hevîyê dimîne.(Lütfi, 2013: 71) Piştî hatina Ebûbekir Efendî ya Cape Townê li herêmê tesîra Osmanîyan zêde dibe. Ebûbekir Efendî li alîyekî bi probleman re eleqedar dibe, li alîyê din jî, ji ber ku rehetîya hin kesên xwedîberjewendî xirab dike û ew kes li hemberî wî pirsgirêkan derdixin, li ber xwe dide. Ev kartêkerî, li ser avasazîyê jî çêdibe. Li gor riwayetan, Ebûbekir Efendî ji bo lihevnekirinan çareser bike bi jinên misilman rezewicîye ên ku eslê wan cuda ne. Di encamê de lihevnekirin hatine çareserkirin, Cape Town gihîşîiye mînakên avasazîyê yên osmanîyan.(Lütfi, 2013: 58)

Ebûbekir Efendî car caran ji Mecmuayê Funûn $^{8}$ re rapor dişandin. Di wan raporan de behsa ehwalê Efrîqaya Başûr û xelkên wê û rewşa misilmanên wê derê dikir. Di yek ji nameyên seyahetnameya Omer Lutfî̀ de wiha hatîye gotin; 'Hin ji xelkên misilman ên vê derê li dor melayan dicivin lê mixabin ev mela îtîqadxirab in û berjewendîyên xwe dixin pêş ya dînê îslamê.' Bi hatina Ebûbekir Efendî, perdeya rûyê van melayên sexte ket û xelkê berê xwe da Ebûbekir Efendî û heqîqetên Îslamî. Ebûbekir Efendî 'eqîdeya rasteqîn a ehlê sunne pêşkêş dikir, wan melayan jî li dijî wî,di çapemenîya herêmî de neşrîyat dikirin, nedihiştin û nedixwestin ku Ebûbekir Efendî teblîxa xwe bi heqî bike. (Lütfi, 2013: 47) Dema ku Ebûbekir Efendî hate Cape Townê, ji bo jiholêrakirina

\footnotetext{
${ }^{6}$ Mülteqa'l-Ebhûr kitêba alimê Osmanî Îbrahîm b. Muhammed el-Helebî (v. 956/1549) ye û wekî berhemek çavkanî di fiqha Hanefî de di medreseyên Osmanîyan de hatîye xwendin. (Has, 1997, 15: 231).

${ }^{7}$ Derbarê Lutfî̀ Efendî de agahiyên vebirî/teqez tunene. Em sedî sed nizanin aya bi rastî jî biraziyê Ebûbekir Efendî ye yan na? Lê Lutfî Efendî ji bo Ebûbekîr Efendî weke bavê xwe yê 'ilmî behs dike. Lutfî̀ Efendî derbarê rêwîtiya xwe ya digel Ebûbekir Efendî û nameyên Ebûbekir Efendî yên ku ji Cape Townê şandine Stenbolê de pirtûkek nivîsandiye ku ev pirtûk him tarîxî ye, him jî ji qelema kesekî wê dewrê, û him ji qelema hevalrêyê Ebûbekir Efendî hatiye nivîsîn gelekî girîng e. Omer Lutfî, ji bo ku alîkariya Ebûbekir Efendî a Efrîqaya Başûr, di 17 gulana 1862an de, bi biryara sultan 'Ebdul'ezîz hatiye erkedarkirin. Ebûbekir Efendî hem wî perwerde kiriye û hem jî seyaheta xwe de bi xwe re gerandiye. Derbarê Omer Lutfî̀ de agahiyên berfireh tunun. Herwiha Omer Lutfî di Seyehetnameya xwe de di hin agahiyan de behsa xwe dike. Bo nimûne; "Ez di mekteba ku Ebûbekir Efendî li Cape Townê vekir de 4 sal mijûliyê perwerdeya zarokan bûm. Ji 40î zêdetir ji van xwendekaran bûne mamoste. Piştî hingê ez ji erkedariya wan rizgar bûm û vegeriyam ser karê xwe yê perwerdehiyê... Ebûbekir Efendî pederê min ê 'ilmî ye. Ez di 5ê Gulana 1866an de bi destûra Ebûbekir Efendî ji Cape Townê derketim û min berê xwe da Stenbolê... Bnr. (Lütfî, 2013: 71-72)

${ }^{8}$ Mecmû'eyê Funûn, Temmûza 1862an heta Çileyê bi serpereştiya Munîf Paşa ve li Setenbolê, ji layê dezgeha Cem'iyyetî 'İlmiyyeyî Osmanîye ve hatiye weşandin. Kovar tenê 47 hêjmar hatine çapkirin. Ji ber ku Ebûbekir Efendi û Munîf Paşa hevdu nasdikirin, Ebûbekir Efendî ji Efrîqaya Başûr name bo wî dişandin da ku çap bibin. Bnr. (Lütfi, 2013: 18)
} 
bawerîyên gel ên te'essûbî û bawerîyên wan ên pûç, dest bi tedrîsatê kir. Bi perwerdehîya 300 xwendekaran re 'eleqedar dibû. Ji van xwendekaran 3 heb bijartibû û ji bo hafiztîyê/jiberkirina Quranê bi taybet perwerde dikir. Bi vî awayî hêvî dikir ku tuxumên xweş û baş ên nû geş bibin û gel ji şaşîyên xwe hişyar bibin û îslamîyet, rast bikeve mala her misilmanekî û hêjmara misilmanan jî zêde bibe. Piştî xebatên bi salan Ebûbekir Efendî serkeftî û serfîrazîya ku bi dest xistîye di nameyekê de wiha rave dike: "Hemd ji Xwedayî re be, cîyawazî û dubendîyên di nava misilmanan de rabûn. Ev jî semereyeke xebatên me bû. Xelkên niştecih fềm kirin ku melayên wan rêşaş in, êdî bi ya wan nakin, bi ya Qurana pîroz dikin. Îxtîlafên ku 40 sal zêdetir e didomin, bi dawî bûn û sukût kirin.”(Gençoğlu, 2016: 32)

Di arşîva îngîlîzan de nûçeyek hatîye dîtin ku piştî çûyîna Ebûekir Efendî bi salekê di rojnameya De Nederlandsche Spectatorê de hatîye weşandin. Ev nûçe girîngîya xebatên Ebûbekir Efendî û serkeftinên wî li ber çavan datîne: "Ebûbekir Efendî li Stenbolê wekî 'alimekî gelekî mezin û navdar tête naskirin. Ji ber vê, îstîdata wî hukûmeta Stenbolê ew bo Cape Townê şandîye û ji bo xebatên fêrkarîyê jî meaşekî zêde didine wî. Divê biçûk neyê dîtin, ji ber ku xîtabî girseyeke biçûk a misilmanan dike. Lewre gelek qebîleyên reşik bi tevahî bi saya xebatên wî ketine dînê îslamê. Bandora Ebûbekir Efendî ya li vê derê ji hedê der e û ji texmînkirinan hê wêdetir e."(Gençoğlu, 2016: 33)

Xebatên Ebûekir Efendî di salên 1870an de li her derên Efrîqaya Başûr berbelav bû. Xwendekarên ku dibûn jiberkerê Quranê û xwendekarên ku têrdar dibûn, ji bo xebatên 'ilmî dihatine şandin bo bajar û dewletên din ên parzemîna Efrîqayê. Ji bilî Cape Townê;Port Elîzabeth, Johannesburg, Kimberley, Durban û hetta Mozambîkê mekteb û camî bi saya serê xwendekarên Ebûbekir Efendî vebûn û Ebûbekir Efendî herwekî serokekî hate pejirandin.

Xizmeteke wî ya din jî ev bû; Ebûbekir Efendî di 49-50 salîya xwe de xwe fêrî zimanê filemenkî dike û piştî ku fêr dibe berhema xwe ya îlmîhalê bi vî zimanî û pîtên "erebî dinivîse: Pirtûka îslamî ya ewil a bi zimanê Efrîqayê hatîye nivîsandin "Beyanûu'd Dîn" a wî ye. Di sala 1876an de li Stenbolê ev berhema wî 1500 nusxe çap dibe. Di arşiva Osmanî de belgeyek nîşan dide ku Siltan Ebdulhemîdê duyem vê pirtûkê wekî dîyarî ji misilmanên Cape Townê re dişîne.(Gençoğlu, 2016: 54)

\section{6. Şampîyonîya Fêrxwazên Mekteba Wî}

Xwendekarên mekteba Osmanîyan a li Cape Townê ji bo demên xwe yên vala bi tiştekî re mijûl bibin dixwazin klûbeke sporê ava bikin. Di wê demê de werzişa herî navdar a Efrîqaya Başûr krîket e. Xwendekarên misilman dixwazin di vê werzişê de xwe pêş va bibin û hedê Rojavayîyên dagirker ên li herêmê bidin zanîn. Di sala 1882an de bi piştgirîya Dewleta Osmanîyan Ottoman Cricket Club (Klûba Krîketê ya Osmanîyan) tê avakirin. Sê hîvên di armaya tîmê de cih digirin nîşaneya hebûna Osmanîyan a li sê parzemînan e. Xebat û antremanên zehmet li dû hevdu tên kirin. Werzişvan heta ji wan tê dixebitin. Klûba Krîketê ya Osmanîyan di sala 1914an de, di lîga herêmî de dibe şampîyon. Tîm êdî li hemû parzemînê dibe nûnerê mezlûm û misilmanan. ${ }^{9}$

Klûba Krîketê ya Osmanîyan a ku ji du tîmên herî berê yên Efrîqaya Başûr yek e dijî tevgerên xwînî yên rejima apartheîd a nijadperest û dijî qeyranên aborîyê yên ji ber Şerên Cîhanê yê Yekem û Duyem çêbûne jî li ber xwe dide. Ji bo ku klûb bijî,

\footnotetext{
${ }^{9}$ https://www.youtube.com/watch?v=bOqVEtsbbT4 (pêgehîn: 21.02.18)
} 
misilmanan hema bibêje sond xwarine. ${ }^{10}$ Piştî bêdengîyekê di sezona 1939-40an de klûb kupaya şampîyonîyê bi rengekî surprîz qezenc dike. Misilmanên wê derê bi ser dikevin ku Kupaya Danîel Ligê bibin muzeya xwe. Wek ku hewcedarîya her kesî bi vê serkeftinê heye xwelîya mirîyan a li ser klûbê reşîyaye ji holê radibe û li dû hevdu serkeftin tên bi destxistin. Şampîyonîyên salên 1942, 1945, 1953 ve 1954 dîsa balê dikşîne li ser Osmanîyan. Pêşbirka Big Eight Competition (Şampîyonîya 8 Mezinan) a sala 1976an dibe sedem ku klûb di qada navneteweyî de navdar bibe. Serkeftina ewil heta salên 2000î, paşê jî heta roja me dewam dike. (Gençoğlu, 2016: 78)

\section{Berhemên Wî}

Ebûbekir Efendîyê ku wargehên li Cape Townê yên ku misilman lê dijîyan zîyaret dikir, di yek ji wan serdanan de dît ku xelkê misilman hîn jî bi xelîfe ve girêdayî ne û bi mebesta ku bi xelkê re zêdetir peywendî bê danîn name şandibû Stenbolê. Ji bilî van xebatan Ebûbekir Efendî bi zimanê erebî û filemenkî dest bi nivîsandina kitêban dike û bi filemenkî şerha wan kitêban dike ku bi erebî nivîsandibû.

Li gorî çavkanyan 8 berhemên Ebûbekir Efendî hene. Ji vana tenê 2 gihaştine ber destê me. Tu agahî derbarê yên din de nehatîye peyda kirin. Yên ku heta roja me hatine yek Beyânu'd Dîn e ya din jî Merâsi'd Dîn e. Ebûbekir Efendî kitêba xwe ya Beyânu'dDînê di sala 1869 de dinivîse. Destxeta orjînal ya vê kitêbê di kitêbxaneye nevîyê wi Muhammed Zubrî Efendî de ye û li gor kitêba çapbûyî hinek cûdahî di destxetê de hene. Ji ber tunebûna çapxaneyan li Copeyê, kitêb di bin hîmaya Abdulhemîd II de di sala 1877an de li Stenbolê hatîye çapkirin. Ev kitêb, wekî kitaba yekemîn tê pejirandin ku di Efrîqaya Ereb de bi tîpin Erebî hatîye çapkirin. (Gençoğlu, 2013: 39; Haron, 2001: 11). Ebûbekir Efendî di muqeddîma kitaba xwe ya Beyânüd'-Dînê de derheqê kitêbên xwe wiha dibêje. "Dema ez çûm Cape Townê û min cehaletîya misilmanên wir dît min dest bi vekirina medreseyekî û nivîsandina kitêban kir ku ev kitêb ji heşt kitêban pêk dihatin. Min di van kitêban de metn bi Erebî șerh bi zimanê misilmanên wir yani bi Cape Dutchî dinivîsi. Bnr. (Brandel-Syrier, 1971: 46)Ji alîyê din ve ew daxûyanîyên ku dibêjin Merâsidü'd-Dîn nehatîye çapkirin ne rastin. Di rastîyê de ji ber pirsgirikên aborîyî ku di Dewleta Osmanîde peyda bibûn Merâsidü'd-Dîn û Beyânu'd-Dîn di sala 1877an de di heman cîldê de têne çapkirin. Di her dû kitêban de jî meseleyên fiqhî li gor mezhebe Henefî̀ hatine şîrovekirin. Di kitêba Beyânu'd-Dînê de mîjarên paqijîi (taharet), nimêj, zikat û rojî li gor fiqha îslamê bi awayekî berfireh hatine îzahkirin. Di Merâsidu'd-Dînê de jî şerjêkirina heywanan û heywanên ku goştê wan helal in, tiştên heram, xwarin û vexwarinên helal û heram, mesleyên nêçîê û w.d. hatine îzeh kirin. (Gençoğlu, 2013: 39, 96-99)

Bi navê Mîftâhud-Dîn jî berhemeke wî heye, lê kitêb bi xwe heta niha nehatîye dîtin. (Gençoğlu, 2013: 54) Tevî ku bandora wî hê jî li ser Efrîqeya Başûr heye û popûlateya xwe bi saya berhema Beyânu'd-Dîn diparêze de, bi fetwaya ku 'xwarina mehsûlên biqalikên behrê li gorî qaîdeyên îslamê heram e', di civata Efrîqaya Başûr de bûye sedema niqaşan. Ev pêşnîyar jî tenê ji alîyê kesayetên rewşenbîr ku bikaribin bûyera bi zanîn û eql şîrove bikin tê fêhmkirin.

Gelê Efrîqaya Başûr bi serkêşîya Mela Tuan Guru misilmantî nas kirin ku ew Şafîimezheb bû û li gor vê mezhebê jî di xwarina hemû mehsûlên behrê de tu fikare xuya nedikirin. Ev jî bû sedem ku angaşta Ebûbekir Efendî ji alîyê hin melayan ve pêrgî

\footnotetext{
${ }^{10}$ https://www.youtube.com/watch?v=Iltzg_upmds (pêgehîn: 21.02.18).
} 
dijatîyê bê. Heçîku misilmanê Cape Townê bi îçtîhada Îmam Şafîi re pihêt giredayî ne û wekî hikmê Quranê dibînin jî̀, dema erka xwe ya Hecê tînin cih îçtîhada îmam Şafî̀ ku di her hal û karî de temasa jinê re destmêjê dişkîne, rîayet nakin û bi îçtîhada Îmam Henîfî erka xwe ya Hecê pêk tînin. Nexwe nakokîya esil di fetwaya Şêx Ebûbekir de nîne, nakokî di tevgerên gel de ye ku gotinên nifşên berê wekî qaîdeyên Qurana pîroz dipejirînin û bêhay tevdigerin. Ebûbekir Efendî di van bîst salên dawî de bala civata zanayên Efrîqaya Başûr kişandîye û di gelek berheman de, bandora Beyanud Dîn a wî eşkere ye. Bêguman yek ji wan jî Ahmed Davidê binecîhê Cape Townê ye. Dîroknas Ahmed David dîyar dike ku Beyanud Dîn a Ebûbekir Efendî berhemek derasayî ya xebata zimannasîyê ye û bi vê taybetmendîya xwe di dîroka Efrîqaya Başûr de pêngavek mezin avêtîye. (Gençoğlu, 2013: 57)

Ebûbekir Efendî derbarê berhema xwe de wiha dibêje: "Hemd minnet û spasî ji Xwedayî re be. Ev e 13 sal in, li vê dermedorê bi karên te'lîm û tefhîmê re mijûl im. Enerjîya ku min di vê biwarê de serf kirîye, semerdar bûye. Ji însanan komeke girseyî piştî ku me'lûmatên dînê mubîn ê îslamê fêr bûn, ji wan jin û mêrên jêhatî li nav eşîr û qebîleyên derdorê de mekteb/dibistan vekirin û dest bi mamostetîyê kirin. Van mamosteyan berhemên min Beyanud Dîn, Merasidd- Dîn çend hebên din îstînsax kirin, bi kopîyên destan zêde kirin û di medreseyan de dane xwendinê. Di demeke kurt de bi saya serê van xebatan, îslam li hemû dermedoran belav bû." (Lütfi, 2013: 75)

\section{Zîyareta Wî Ya Stenbolê}

Ebûbekir Efendî, berhemên bi navê Beyanu'd-dîn û Merasidu'd-dîn dinivîse ku ev herdu berhem ji berhemên wî yên herî girîng in. Ebûbekir Efendî berhema xwe ya bi navê Beyanu'd-dînê ku çavkanîya wê Multeka'l-ebhura Halebî ye di sala 1869an de temam dike û nusxeyeke wê dişîne Stenbolê. Bi wesîleya kitêbê di 13ê Tîrmeha sala 1870an de bi nîşana Mecîd a ku di pileya çaran de ye tête xelatkirin. Ebûbekir Efendî ev herdu berhemên xwe bi xwe îstînsax dike û ji xelkê re belav dike; lê ev yek têra xelkê nake û bo bên çapkirin di îlona sala 1877an de Ebûbekir Efendî diçe Stenbolê. Digel atmosfera neyînî ya ku ji ber şerê di navbera Osmanî û Rûsan de derketibû, Ebûbekir Efendî bi şiklekî pir baş û xweşik tête pêşîwazîkirin. Çapkirina kitêbên wî di Encumenî Maarîfề de tête nirxandin û teklîfa ji her berhemekê, çapkirina 1500 hejmaran tête pejirandin. Beyanu'd-dîn berhema herî kevin û berfireh a herêmê ye ku bi zimanê mehelî ya herêmê hatîye nivîsandin û çapkirin ku ev yek jî bala rojhilatnasan kişandîye û berhem ji alîyê Mia Brandel - Syrier ve bi îngilîzî hatîye tercimekirin. (The Religious Duties of Islam as Taught and Explanied by Abu Bakr Effendi, Leiden 1960) Ebûbekir Efendî di raportekê de ku dabû navenda hukûmetê destnîşan kiribû ku, îngilîz hewildanên şexsî yên teblîxa Îslamê asteng nakin û ji ber vê yekê jî dîyar kiribû ger xoceyên zimanzan, bi exlaq û îdealîst bên şandin ev yek, dê ji bo belavbûna îslamê ya li herêmê xizmetê bike.

\section{Wefata Wî Û Wesîyeta Wî}

Ebûbekir Efendî 29ê hezîrana 1880an de li Cape Townê wefat dike. Li goristana Barû hatîye definkirin. Di nameyên xwe de ku berî wefata xwe ji Ehmed Cevdet Paşa re şandine, hin wesîyetên xwe vedibêje. Li gorî çavkanîyên berdest 3 qonax û 7 xanîyên Ebûbekir Efendî li Cape Townê hene. Dixwaze mîrasa wî li zarokên wî bêne parvekirin. Lê eger ji zarokên wî yên ku ji dînê îslamê derketibin hebin, divê ji mîrasê para wan tunebe. Ev teqsîmat jî piştî ku zarokê wî yê herî biçûk gihişte 21 salîya xwe divê bête kirin. (Uçar, 2008: 244) Nameya wî ya dawî de ku ji Ahmed Cevdet Paşa re şandîye, tam metnekî wesîyetnameyê tê de veşartîye. Ebûbekir Efendî wiha dibêje; eger ez li vê 
derê wefat bikim, li gorî zagona hukûmeta vê derê, dê kitêbên min, akaratên min, xanîyên min û saîr eşyayên min bêne desteserkirin. Ji ber ku ez teb'ayê/hemwelatîyê vê derê me, dê nikaribim mal û milkê xwe zebtûrebt bikim. Eger dewleta 'alîye 'înayet bike û ji Şahbanû Viktorîya re vê keyfîyeta min rave bike û eger wekîlên Osmanî himmetê bikin û ji balyozxaneya vê derê re rewşa min binivîsin, dê hikumeta vê derê nikaribe dest deyne ser milkê min. Min vê carê kurê xwe, bendeyê we Ehmed 'Etaullah şande xakêpayê we. Min li Nûrî Osmanîye sêpare qonaxek ku li kêleka qonaxa hezretî Munîf Efendî bû, bi sêsed lîrayî kirîbû. Ez dixwazim cenabê we emir bide da ku bête firotin û pereyê vê qonaxê hûn çawa munasib dibînin wisa belav bikin/serf bikin. Eger ku emrê Xweda hat û ez wefat bikim, 5 zarokên min hene. Biçûk in, xerîb in û bê xwedan in. Eger li vê derê bimînin, pir ditirsim dema ku mezin bibin dînê xwe biguherînin. Ez we wasîyî muxtar dibijêrim, ricakar im, 'înayet bikin. Hem jî zarokên min meraqawer in. Dixwazim bi saya kesekî hûn wan 'ewdetî bo Stenbolê bikin. Li wê derê bila fêrî dînê xwe bibin. Herçend ku mijûlîya we fewqel'ade be jî, ez tika dikim li van keyfîyetan himmetê bikin, belam zarokên min bêxwedan in. (Gençoğlu, 2013: 80; Uçar, 2008: 244-245) Çi bi ser mal û milkê wî hatîye em pê nizanin. Lê daxwaza wî ya ku digot bila zarokên min biçine Stenbolê pêk nehatîye. Herwiha qonaxa wî ya Stenbolê jî çi bi ser hat ne dîyar e, ango di çavkanîyan de em rastî agahîyekê ya di vê biwarê de nehatin.

\section{Encam}

Ebûbekir Efendî bi fealîyetên xwe bû wesîle ku cemaeta misilman a li herêmê bibe xwedîyê nasnameyeke nû. Herwisa serfiraz bûye ku misilmanên wê derê, her 4 mezhebên heq qebûl bikin û yekîtîya civatî û dînî di nav xwe de tesîs bikin. Ew mektebên ku wî vekirin wekî pêşîvanên sazîyên perwerdehîya îslamî yên li herêmê tên hesibandin û niha jî li wê derê komeke cemaeta misilman a ku nevîyên Ebûbekir Efendî jî di nav de ne, hebûna xwe didomînin.

Wek encam, Ebûbekir Efendî, di nav 17 salan de ku li Efrîqaya Başûr maye, dibe wesîle ku bi sedan xwendekar bigihije. Wisa ku xwendekarên wî piştî salan li Londonê jî mizgeft dane çêkirin. Cape Towna ku îro nifûsa wê 3,5 milyon e, sê paran yek ji misilmanan pêk tê ku ev hinekî bi saya wî bûye. Pişti wefata wî û piştî ku kurên wî mezin bûn, karên bavê xwe domandin, bi taybet Ehmed 'Etaullah û Hîşam Nimetullah Efendî. Ji ber ku Ehmed 'Etaullah di sala 1886an de bar dike diçe bajarê Kîmberleyê, paşê jî di sala 1901ê de bûyîna wî ya balyozê Sîngapûrê, rawestîneke xizmetên îslamî yên Cape Townê encam dide. Loma ji nû ve gelên misilman ên Cape Townê, 'alimekî din ji Stenbolê dixwazin.

Bi xebatên Ebûbekir Efendî li Cape Townê, gelek camî hatin avakirin, gelek medrese vebûn û zanîna 'ilmê îslamê li wê derê pêş ket. Ebûbekir Efendî di hin nameyên xwe de behsa kesên ku bête şandin bo cîgehên wisa, divê xwedan çi xisûsîyetan bin, eşkere dike. Tecribeyên xwe tîne ziman û ji saderetê dixwaze ku kesên zîrek û 'âlim û salih û pirzimanî bêne peywirdarkirin.

Ebûbekir Efendî di civata misilman a Efrîqaya Başûr de xwedan vîzyoneke taybet bû. Herkesî bi wî bawer dikir, bawermend an ne bawermend her kesî bi dilnîyayî ji wî behs dikir. Loma bandora wî gelekî mezin bû. Bi damezrandina mekteba xwe ve, vê bandora wî bi salan dewam kirîye, hê jî ev tesîr berdewam e. Meriv dikare bi asayî bêje ku Efrîqaya Başûr bi du beşan ve dikare bê dabeşkirin ji alîyê jîyana îslamî ve: Berî 
Ebûbekir Efendî û piştî Ebûbekir Efendî. Lewre bi rastî jî Ebûbekir Efendî ekolek bû û cedîdîyeke nû li wê derê pêk anî.

Piştî wefata wî, mîrasa wî ya kulturî û xwendekarên wî yên jêhatî xizmetên wî domandin. Îro jî divê hereketên îslamî yên dewletên bîyanî, sîstema xizmeta Ebûbekir Efendî vekolin û ji wê sûd wergirin.

\section{Jêder}

Aras, Osman Nuri. Akîyla Karasîyla Güney Afrika. Buku: Bepres, 2004.

Baktır, Mustafa -Eraslan, Cezmi. Türkiye Diyanet Vakfi İslâm Ansiklopedisi. 10: 276277. İstanbul: TDV Yayınları, 1994.

Brandel-Syrier, Mia (ed.). The Religious Duties of Islam as Taught and Explained by Abu Bakr Effendi: A Translation from the Original Arabic and Afrikaans. İstanbul: EJ Brill, 1971.

Brigaglia, Andrea. Abu Bakr Effendi A Report on the Activities and Challenges of an Ottoman Muslim Theologian in the Cape of Good Hope. Teza Masterê, University of Cape Town, 2013.

Bruinessen, Martin Van. Mullas, Sufis and Heretics: The Role of Religion in Kurdish Society: Collected Articles. Istanbul: İsis, 2000.

Bruınessen, Martin Van. 'Ondokuzuncu Yüzyılda Güney Afrika'da Bir Osmanlı Kürt Alimi: Ebubekir Efendi”. Hece Dergisi (Haziran 2017): 578-593.

Davids- da Costa, Achmat-Yusuf. Pages from Cape Muslim History. Pietermaritzburg: Shuter \& Shooter, 1994.

Gençoğlu, Halim. Güney Afrika'da Osmanlı İzleri. İstanbul: Tezkire Yayınları, 2016.

Gençoğlu, Halim. "The first Muslim politician of South Africa Ahmet Ataullah Bey, 1865 - 1903”. New Contree 69 (July 2014): 93-119.

Haron, Muhammed. "The Making, Preservation And Study Of South African Ajami Mss And Texts". Sudanic Africa 12 (2001): 1-14.

Has, Şükrü Selim. "Halebî, İbrahim b. Muhammed". Türkiye Diyanet Vakfi İslâm Ansiklopedisi. 15: 231-232. İstanbul: TDV Yayınları, 1997.

Hazar, Numan. Küreselleşme Sürecinde Afrika ve Türkîye-Afrika Ilişskileri. Ankara: Usak Yayınları, 2011.

Köprülü, Orhan F. "Efendi”. Türkiye Diyanet Vakfi İslâm Ansiklopedisi. 10: 455-456. İstanbul: TDV Yayınları, 1994.

Kurtuluş, Rıza. "Güney Afrika Cumhurîyeti”. Türkiye Diyanet Vakfi İslâm Ansiklopedisi. 14: 299-303. İstanbul: TDV Yayınları, 1996.

Lütfî, Ömer. Yüz Yıl Önce Güney Afrika, Ümitburnu Seyahatnamesi. İstanbul: Kitapevi Yayınları, 2013.

Marufoğlu, Sinan. Osmanl Döneminde Kuzey Irak (1831-1914). İstanbul: Eren Yayıncilık, 1998. 
Orakç1, Serhat. The Ottoman Legacy in South Africa: A Historical Analysis of the Emerging Links Between South Africa and the Ottoman Empire Between 1861-1923. LAP Lambert Acad. Publ., 2011.

Seben, H. Taner. Singapur'daki ilk Temsilciliklerimiz ve Başkosolos Ahmed Ataullah Efendi. Singapur: Singapur Büyükelçilikği Yayınları, 2014.

Selms, A. Van. "Guney Afrikada Bir Turk Alimi”. çev. Yusuf Ziya Kavakcı. Diyanet Ilmi Dergi, 3 (1976): 168-174.

Uçar, Ahmet. 140 Yıllık Miras Güney Afrika'da Osmanlılar. İstanbul: Tez Yayınları, 2001.

Uçar, Ahmet. Güney Afrika'da Osmanlılar. İstanbul: Çamlıca Yayınları, 2008.

Yaran, Rahmi. "Bilmen, Ömer Nasuhi”. Türkiye Diyanet Vakfi İslâm Ansiklopedisi. 6:162-163. İstanbul: TDV Yayınlar1, 1992.

http://www.millîyet.com.tr/islam-tarihcisi-ogrencilerle-bir-araya-siirt-yerelhaber1862908/ (pêgehîn: 20.02.18).

https://www.youtube.com/watch?v=bOqVEtsbbT4 (pêgehîn: 21.02.18).

https://www.youtube.com/watch?v=Iltzg_upmds (pêgehîn: 21.02.18). 


\section{PÊVEK}

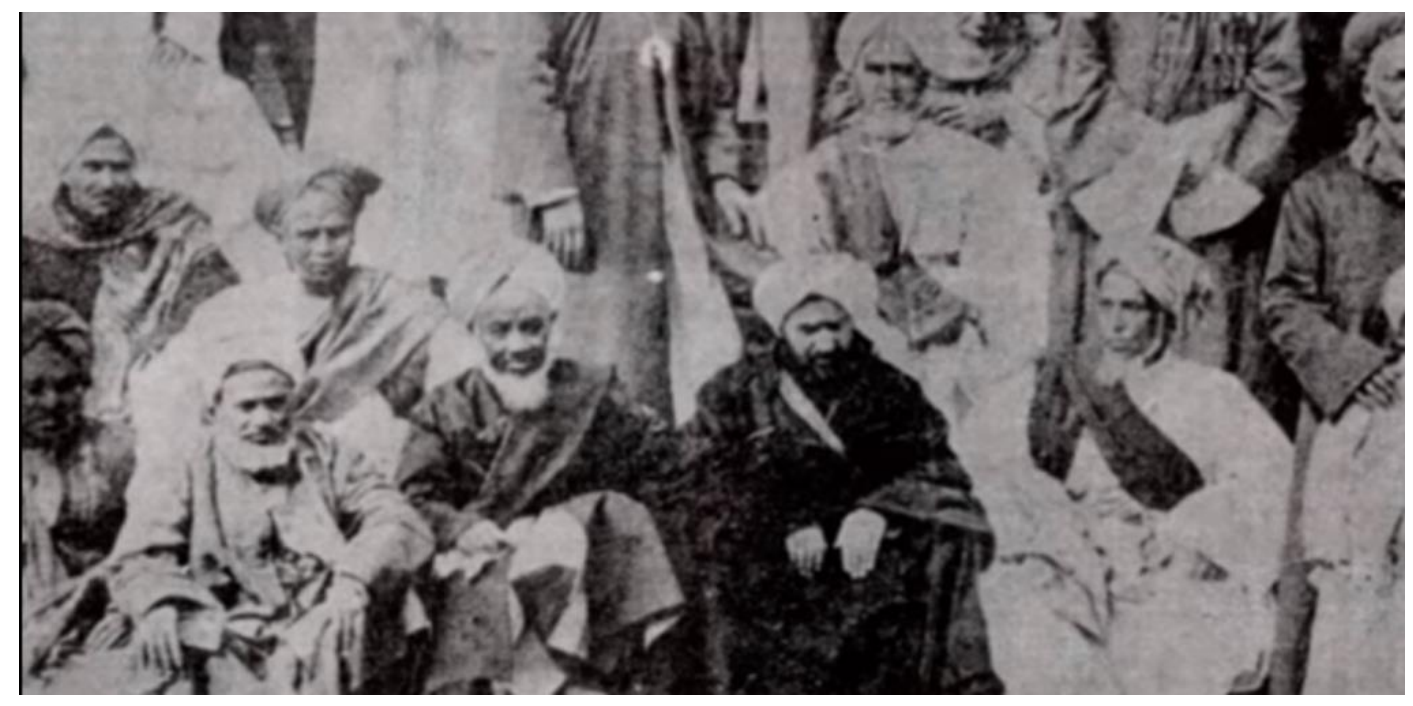

1. 16 Çile 1863 tekane wêneyê Ebûbekir Efendî Li Efrîqaya Başûr

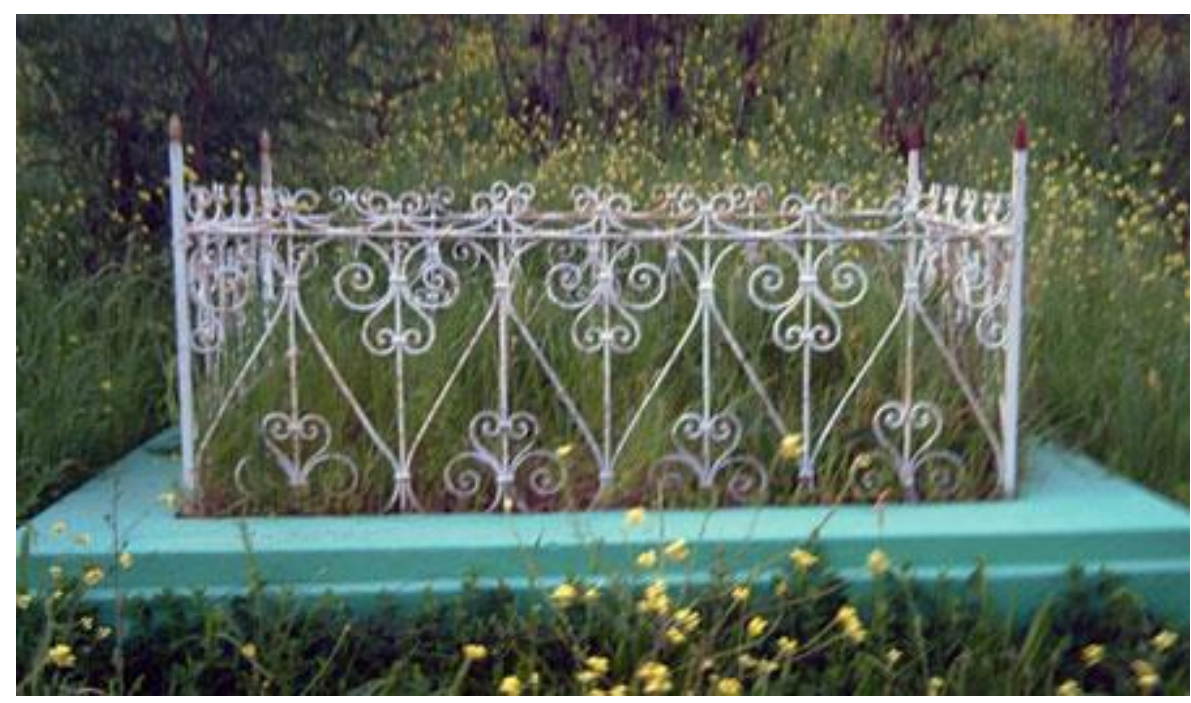

2- Gora Ebûbekir Efendî Li Cape Townê 


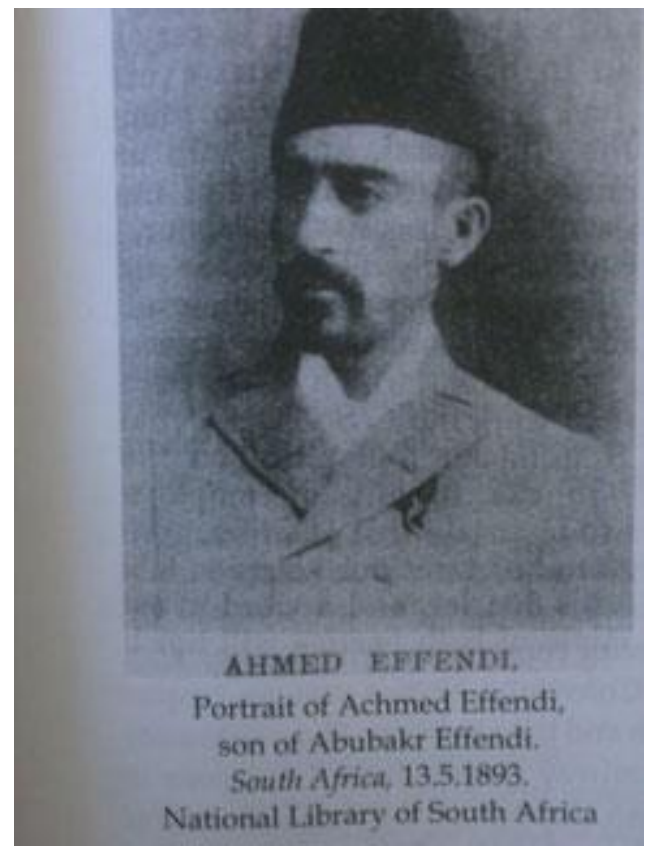

3- Kurê Ebûbekir Efendî Wî Ehmed Etaullah Efendî

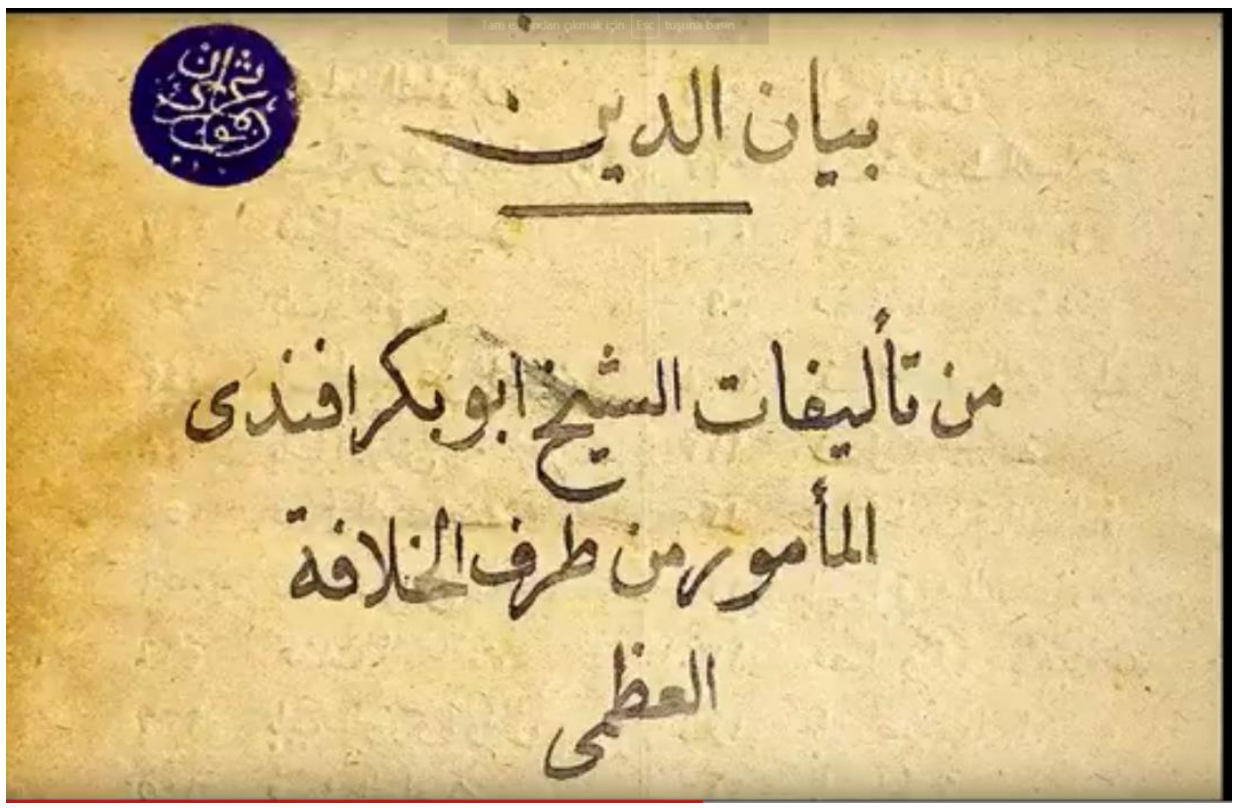

4- Bergê Berhema wî, Beyanuddîn 


$$
\begin{aligned}
& \text { تربية الصبد القرَشي الأمجدي } \\
& \text { المأمور من جهة الخلافة والورلة العُشاية } \\
& \text { لثثر علوم الين والمعارف الرباتية في هذه الأتطر }
\end{aligned}
$$

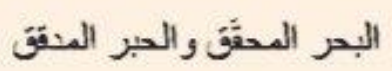

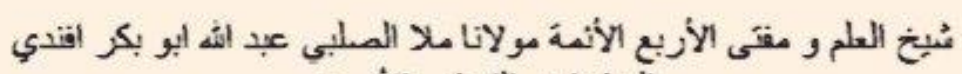

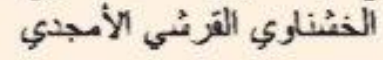

The Education and Descent

$$
\text { of }
$$

The Sayyid Al-Qurashiy Al-Amjadiy

The Commissioner from the Department of the Caliphate and the Ottoman State

to spread the Science of Religion and Divine Knowledge in these countries (of Southern Africa).

The Universal Investigative Scholar and Scribe of Detailed Precision, The Sheikh of Knowlexge and Mufti of The Four Imams,

Mullah Maulana Abdullaah Abu Bakr Effendi

Al-Khushnaawiy Al-Qurashiy Al-Amjadiy.

5. Erkedarîya wî û hin taybetîyên wî (https://twitter.com/halimgenc1 erişim: 11.01.2019)

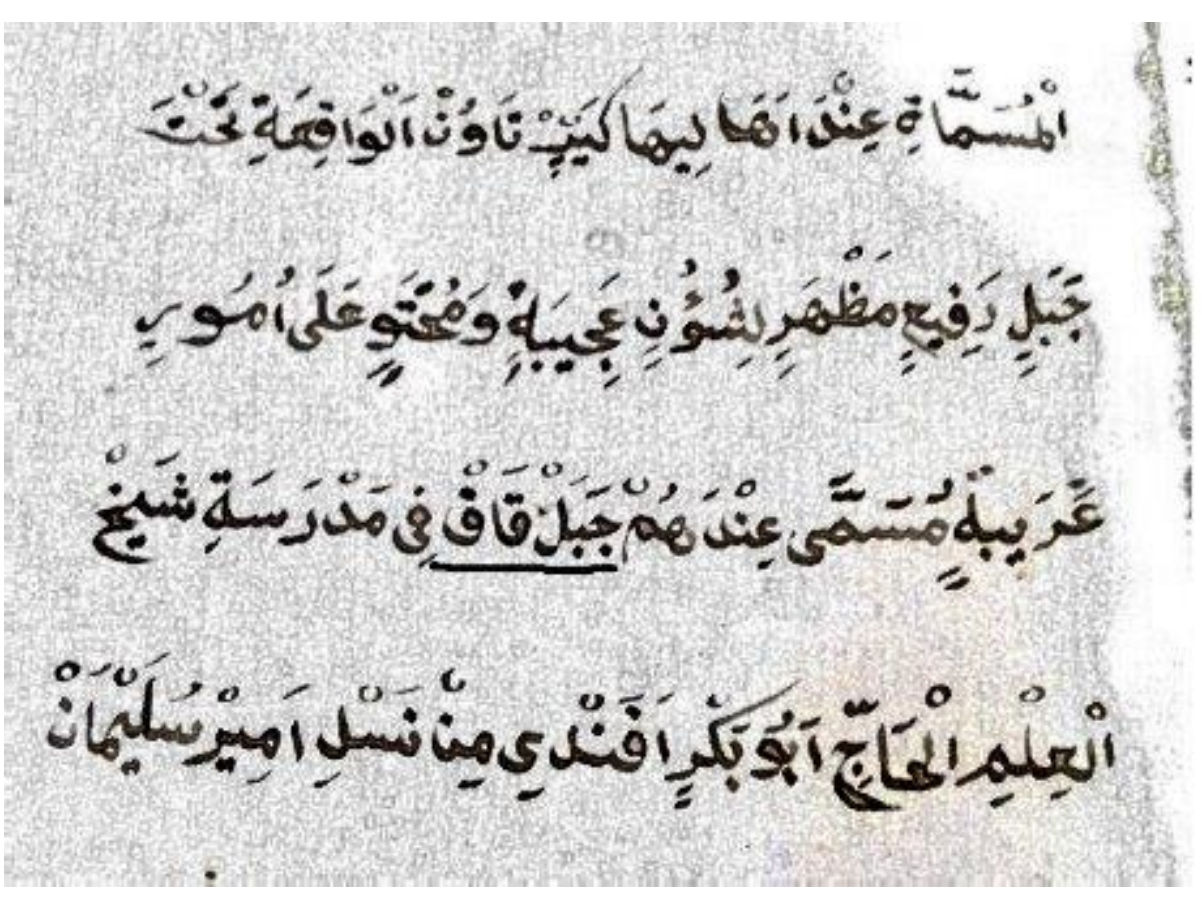

6. Neseba Wî 


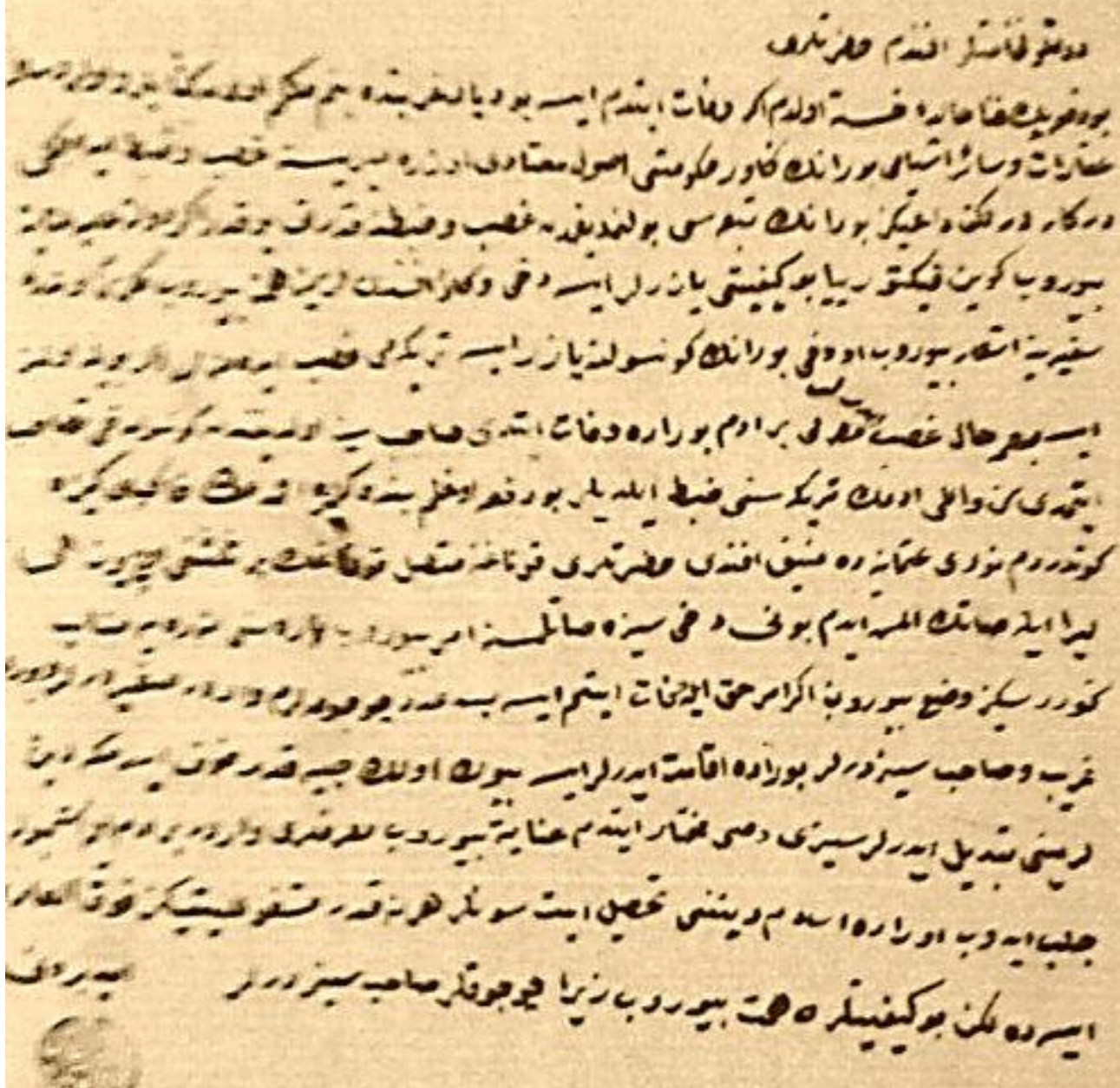

7. Nameyeke wî bo Ahmet Cevdet Paşa, bi destxeta wî (https://twitter.com/halimgenc1 erişim: 11.01.2019) 


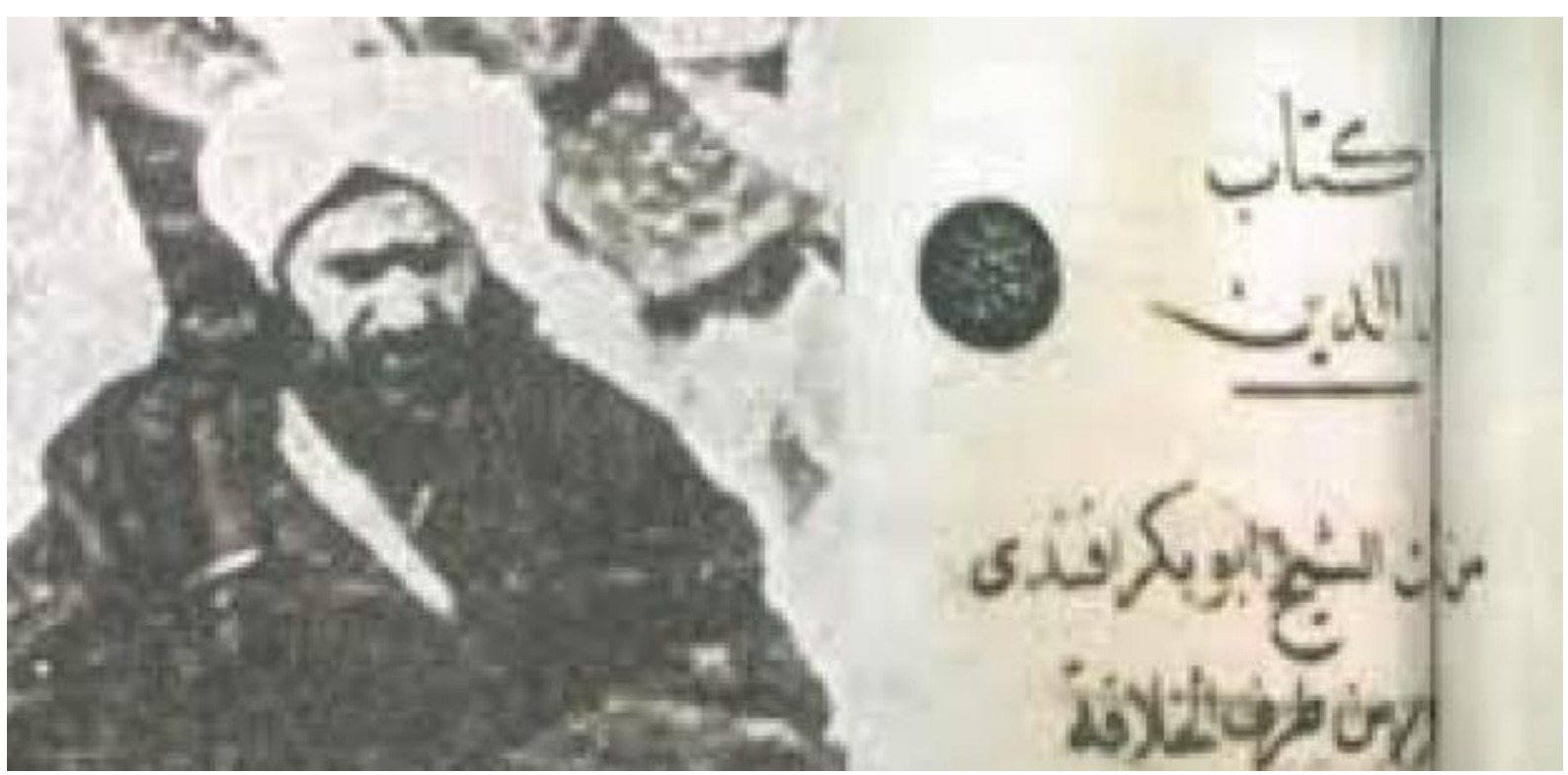

8. Wêneyê wî, ji nêz ve 


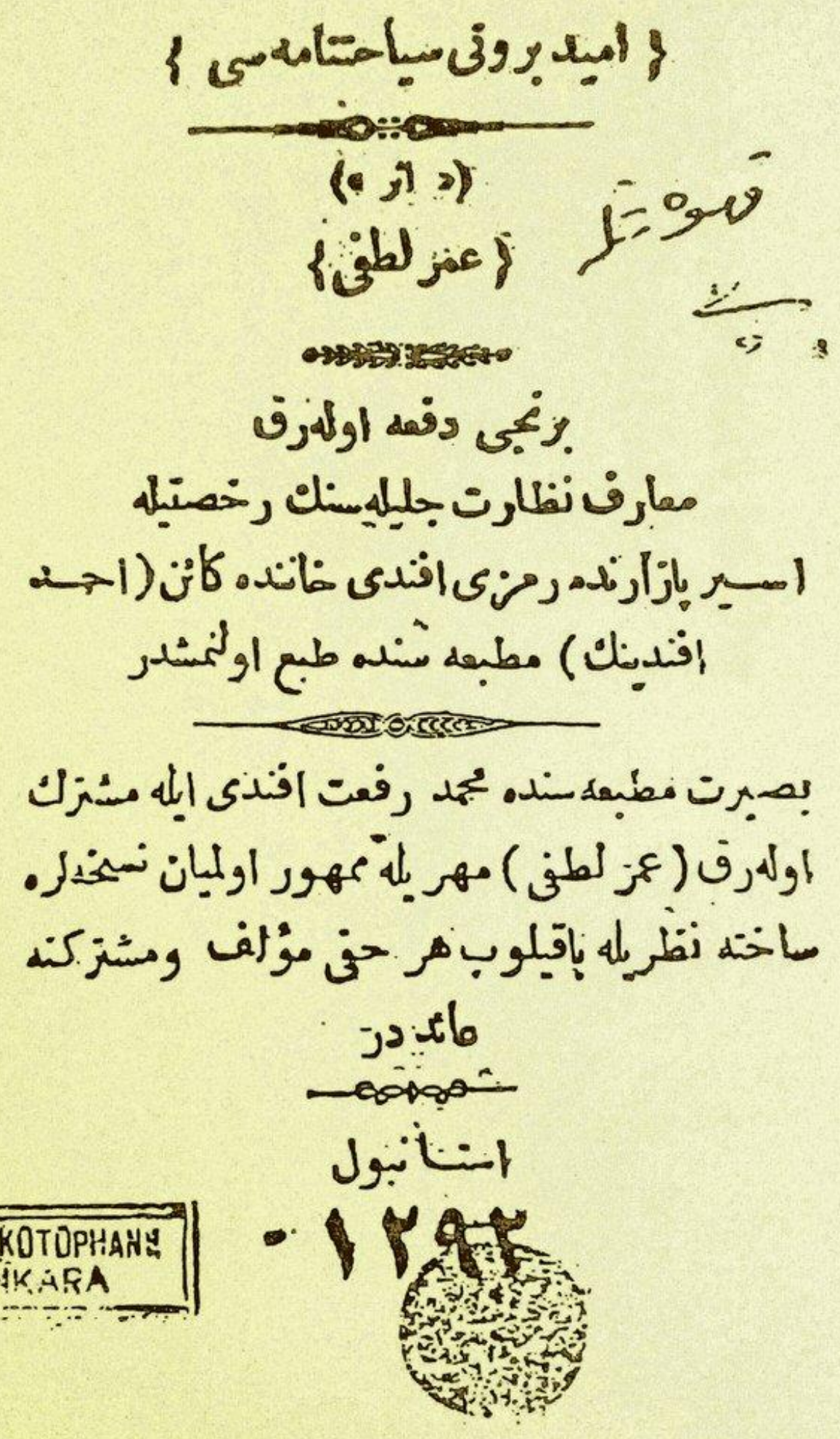

9. Berga Resen a Seyahetnameya Lüitfî Efendî 


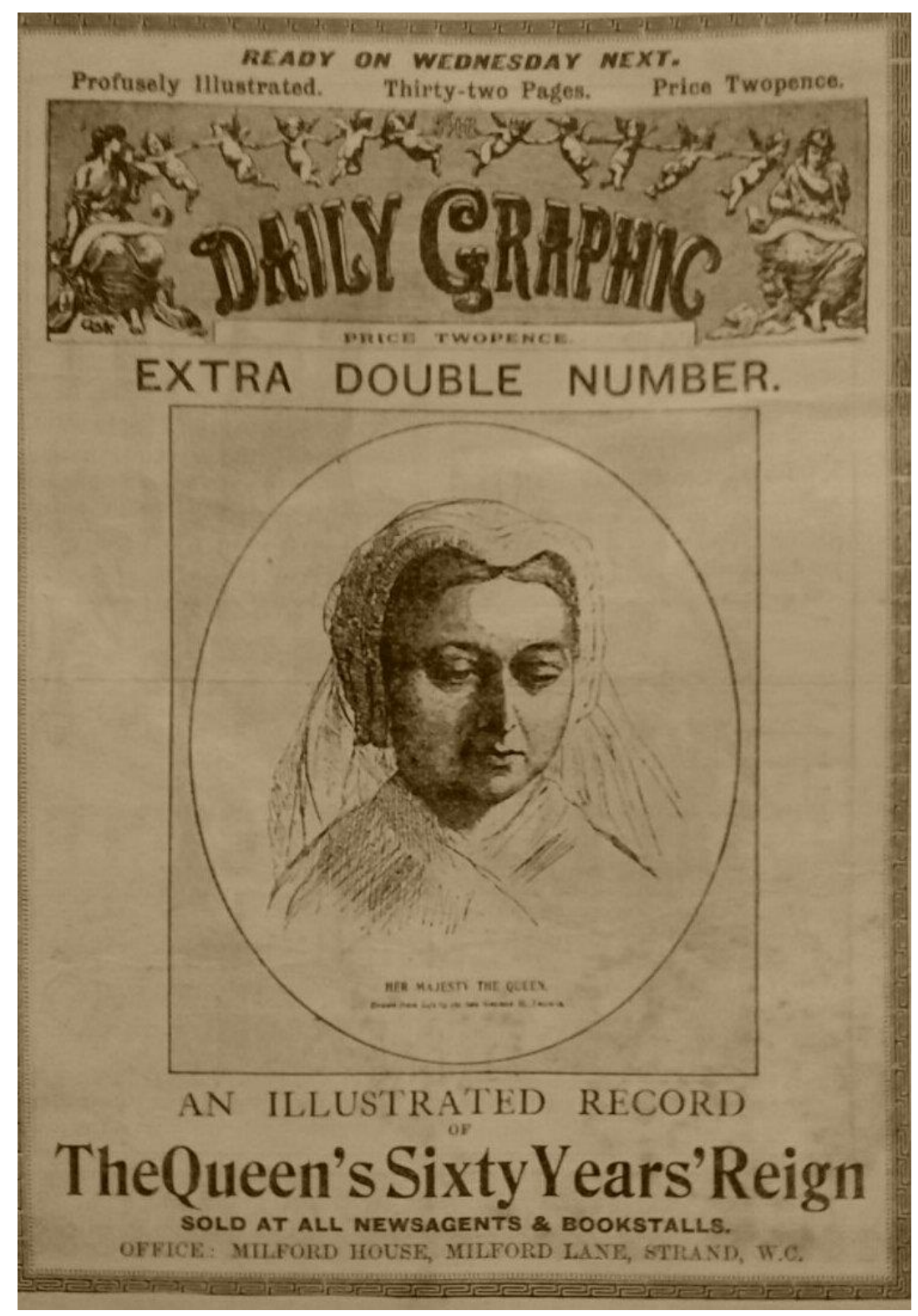

10. Wêneyê Qralîçeya Îngilistanê ya ku daxwaza alimekî a Cape Townîyan ragihandibû bo Siltan 'Ebdulezîz, Queen Viktorya. (Halim Gençoğlu-Cape Town Milli Arşivi, Golden Collection: 2/327) 


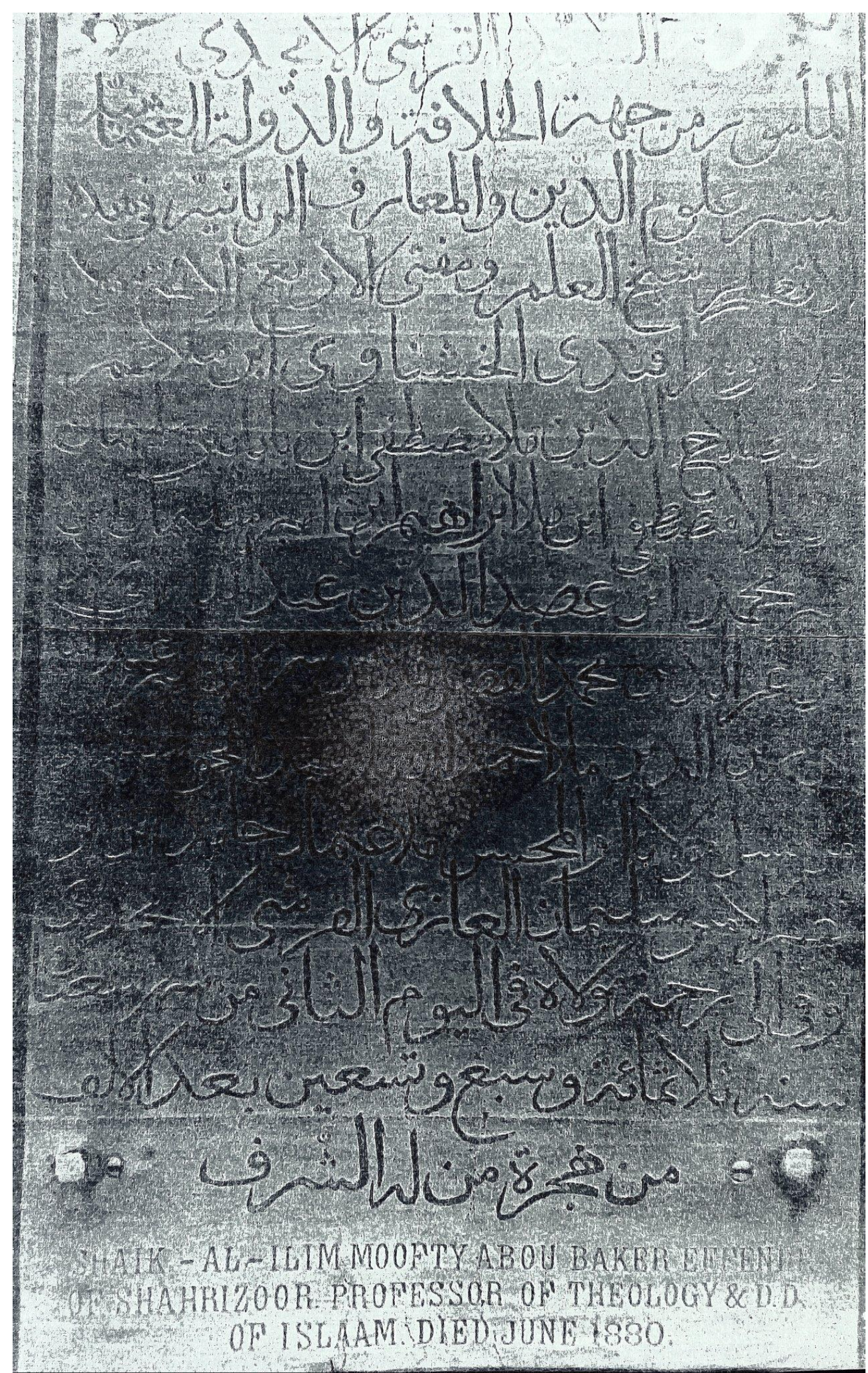

11-Navên Bav û Bapîrên Ebûbekir Efendî (https://twitter.com/halimgenc1 erişim: 11.01.2019) 


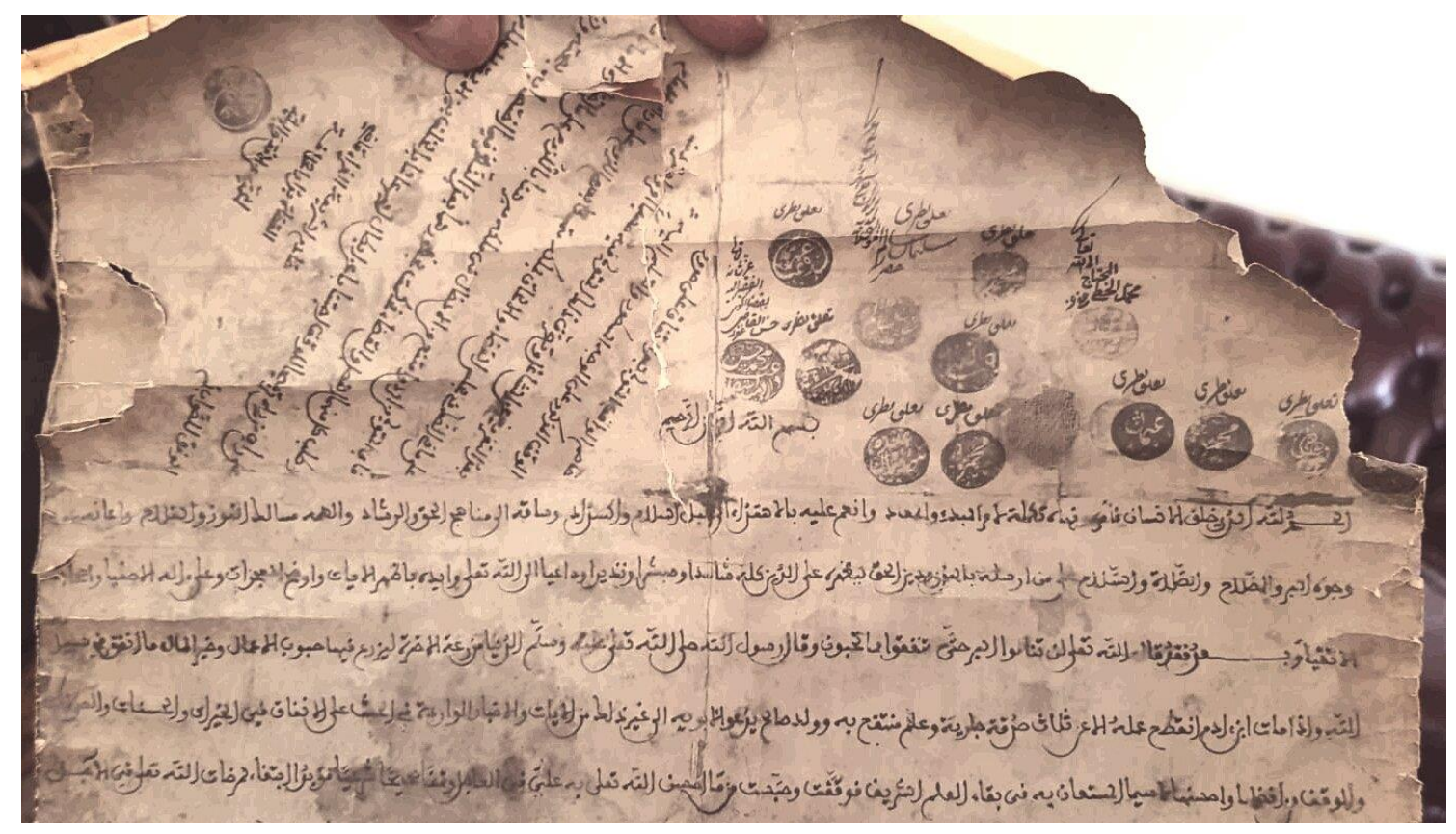

12. Berat, mohr û qeydên weqfan ên bav û bapîrên Ebûbekir Efendî. (Halim Gençoğlu-Cape Town Milli Arşivi, Golden Collection) 


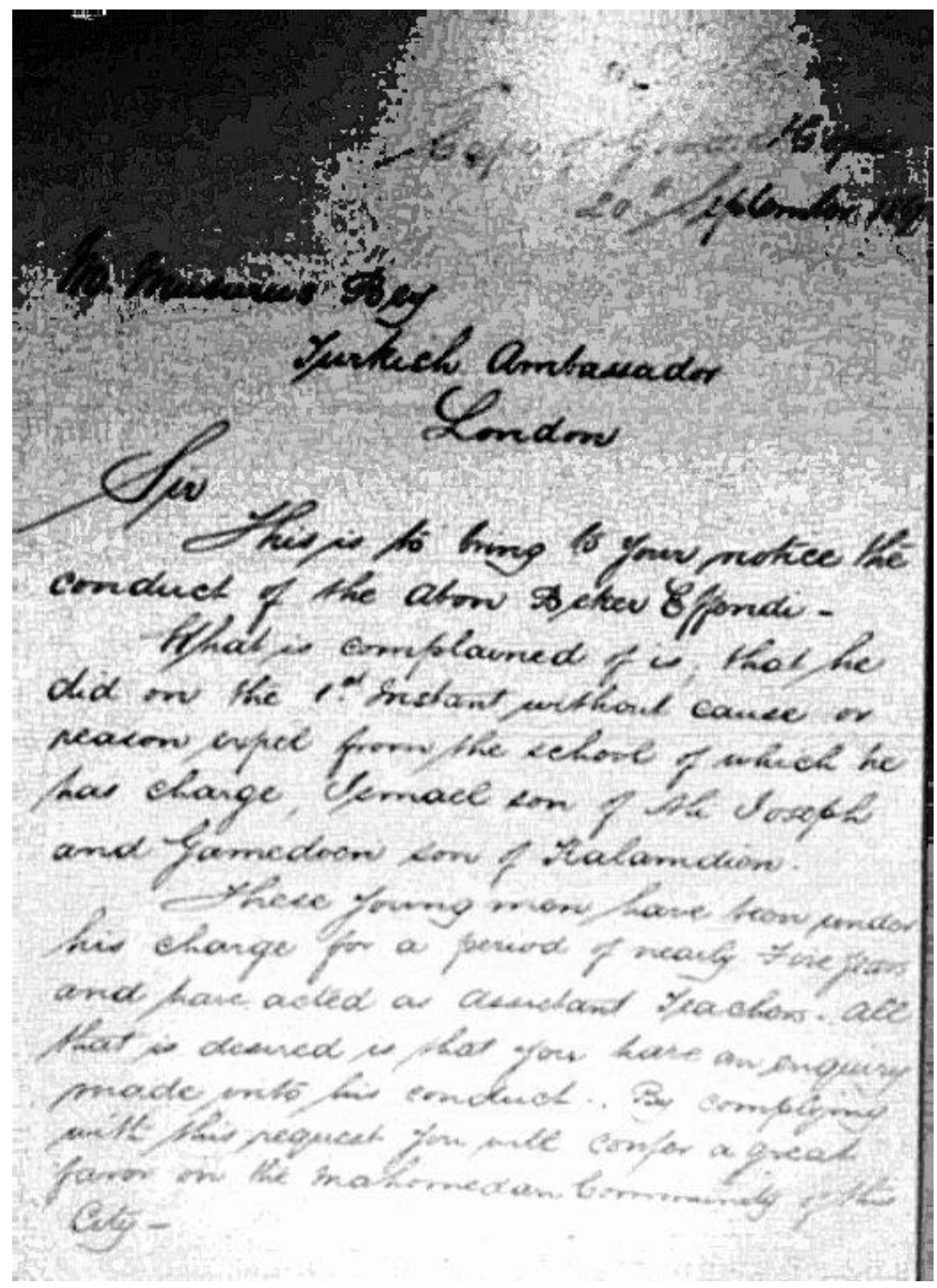

13- Nameyek. Ebûbekir Efendî Li Mekteba Osmanî ya Cape Townê 2 xwendekarên xwe diqewirîne. Welîyên xwendekaran nikarin Ebûbekir Efendî qani' bikin. Loma rica û lava ji Sefîrê Londra Mûsûrûs Paşa dikin da ku bibe palpişt ku zarokên wan hilde mektebê. (https://twitter.com/halimgenc1 erişim: 11.01.2019) 


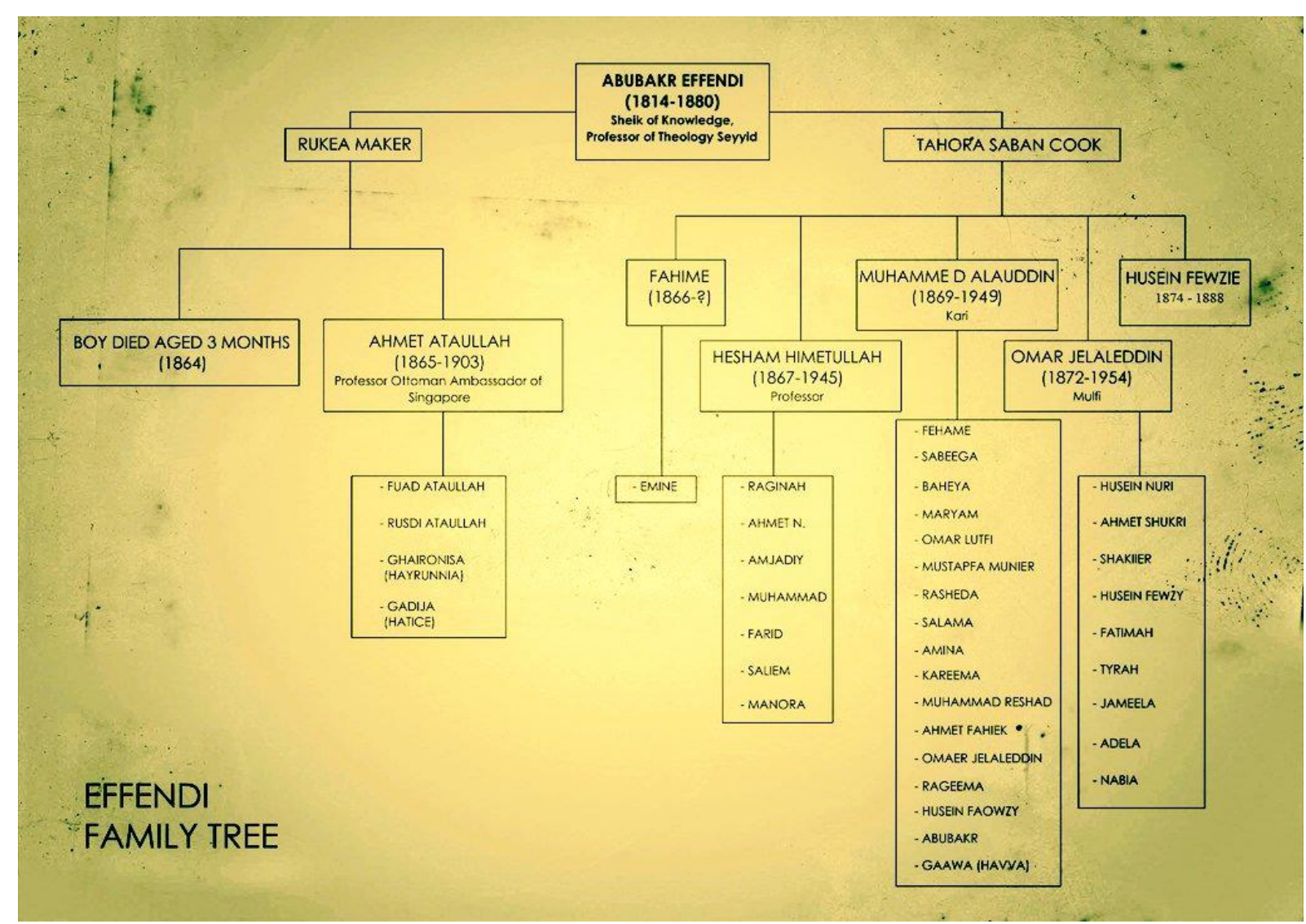

14- Ebûbekir Efendî û şecereya piştî wî ya li Cape Townê (https://twitter.com/halimgenc1 erişim: 11.01.2019) 